Prepared in cooperation with the State of Idaho, Idaho Power Company, and the Idaho Department of Water Resources

\title{
Evaluation of Seepage and Discharge Uncertainty in the Middle Snake River, Southwestern Idaho
}

Scientific Investigations Report 2014-5091 
Cover: Streamgage operated by Idaho Power Company on the Snake River below Swan Falls Dam near Murphy, Idaho (13172500), looking downstream. Photograph taken by Molly Wood, U.S. Geological Survey, March 15, 2010. 


\section{Evaluation of Seepage and Discharge Uncertainty in the Middle Snake River, Southwestern Idaho}

By Molly S. Wood, Marshall L. Williams, David M. Evetts, and Peter J. Vidmar

Prepared in cooperation with the State of Idaho, Idaho Power Company, and the Idaho Department of Water Resources

Scientific-Investigations Report 2014-5091 


\title{
U.S. Department of the Interior SALLY JEWELL, Secretary
}

\section{U.S. Geological Survey Suzette M. Kimball, Acting Director}

\author{
U.S. Geological Survey, Reston, Virginia: 2014
}

For more information on the USGS - the Federal source for science about the Earth, its natural and living resources, natural hazards, and the environment, visit http://www.usgs.gov or call 1-888-ASK-USGS

For an overview of USGS information products, including maps, imagery, and publications, visit http://www.usgs.gov/pubprod

To order this and other USGS information products, visit http://store.usgs.gov

Any use of trade, firm, or product names is for descriptive purposes only and does not imply endorsement by the U.S. Government.

Although this information product, for the most part, is in the public domain, it also may contain copyrighted materials as noted in the text. Permission to reproduce copyrighted items must be secured from the copyright owner.

Suggested citation:

Wood, M.S., Williams, M.L., Evetts, D.M, and Vidmar, P.J., 2014, Evaluation of seepage and discharge uncertainty in the middle Snake River, southwestern Idaho: U.S. Geological Survey Scientific Investigations Report 2014-5091, 34 p., http://dx.doi.org/10.3133/sir20145091.

ISSN-2328-0328 (online) 


\section{Contents}

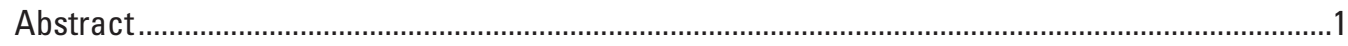

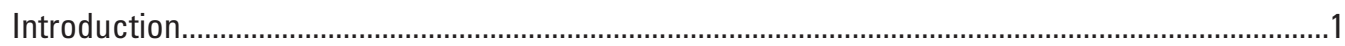

Description of Partial Decrees for Water Rights in the Middle Snake River...........................3

Removal of Idaho Power Company Operations from Discharge Calculations ..........................

Purpose and Scope .........................................................................................................

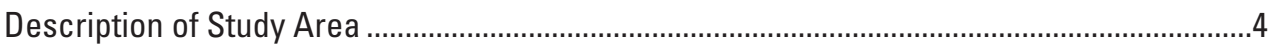

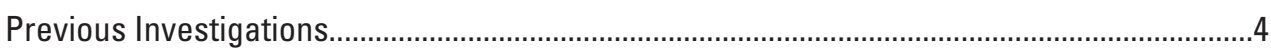

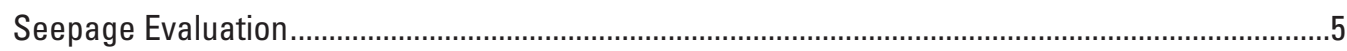

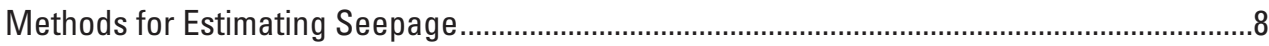

Discharge Measurements for Calculating Seepage ........................................................

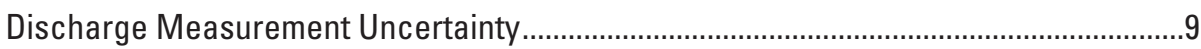

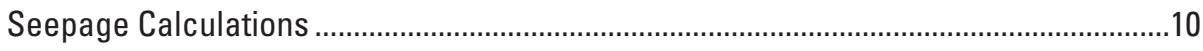

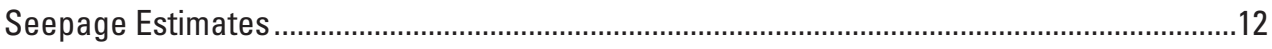

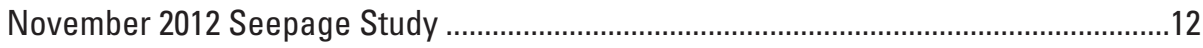

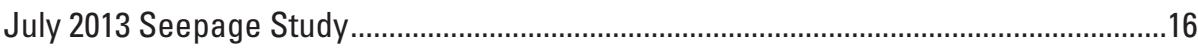

Comparison of Results from November 2012 and July 2013 Seepage Studies ...............21

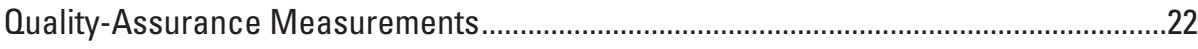

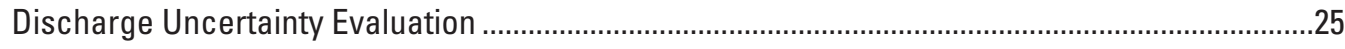

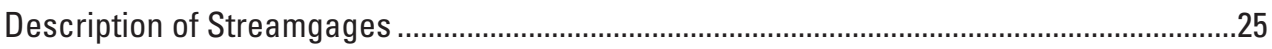

Snake River below Lower Salmon Falls Dam, near Hagerman, Idaho

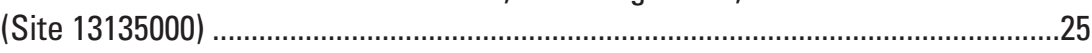

Snake River below Bliss Dam, near Bliss, Idaho (Site 13153776) .....................................25

Snake River below C J Strike Dam, near Grand View, Idaho (Site 13171620).................25

Snake River below Swan Falls Dam, near Murphy, Idaho (Site 13172500) ......................25

Methods for Estimating Discharge Uncertainty ...............................................................26

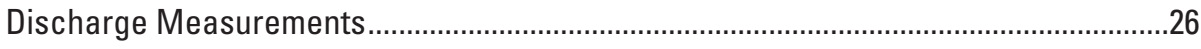

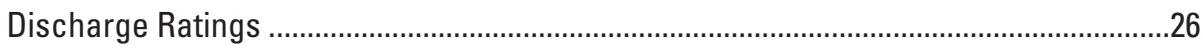

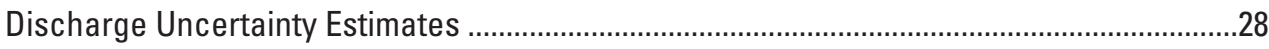

Snake River below Lower Salmon Falls Dam, near Hagerman, Idaho

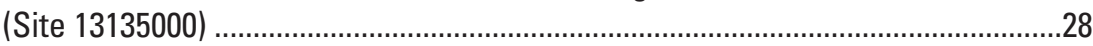

Snake River below Bliss Dam, near Bliss, Idaho (Site 13153776) ....................................28

Snake River below C J Strike Dam, near Grand View, Idaho (Site 13171620)..................28

Snake River below Swan Falls Dam, near Murphy, Idaho (Site 13172500) .....................29

Implications for Measuring and Reporting Discharge at the Murphy Streamgage .................30

Potential Opportunities for Reducing Uncertainty ...............................................................30

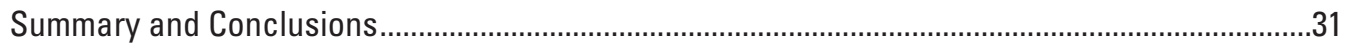

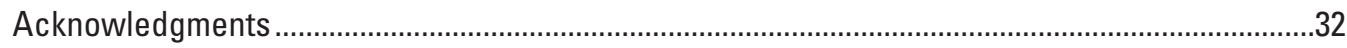

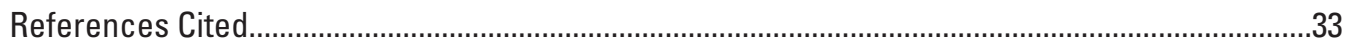




\section{Figures}

1. Map showing locations of streamgages in the study area, middle Snake River, southwestern Idaho

2. Map showing locations of measurement sites during the November 2012 seepage study, middle Snake River, southwestern Idaho.

3. Map showing locations of measurement sites during the July 2013 seepage study, middle Snake River, southwestern Idaho

4. Photograph showing measurement of discharge with an acoustic Doppler current profiler deployed in an inflatable kayak at main-stem site 14, middle Snake River, southwestern Idaho

5. Graph showing discharge measurements selected and grouped for calculation of seepage in the middle Snake River, southwestern Idaho, July 16-17, 2013.

6. Graph showing estimated seepage gains and losses relative to measurement uncertainty for selected reaches of the middle Snake River, southwestern Idaho, November 26-28, 2012

7. Graph showing average water-table elevations measured in wells on the Mountain Home Air Force Base, September 2012-13, and seepage estimates in selected reaches between main-stem sites 4 and 5 , and 5 and 11, middle Snake River, southwestern Idaho, November 2012 and July 2013

8. Graph showing index-velocity ratings used to calculate prediction intervals at Adjusted Average Daily Flow thresholds and selected warning levels for the Snake River below C J Strike Dam, near Grand View, Idaho.

9. Graph showing computed average daily discharge and 95-percent prediction intervals for discharges less than 10,000 cubic feet per second at streamgage Snake River below Swan Falls Dam, near Murphy, Idaho (13172500), water year 2011

\section{Tables}

1. Streamgages operated by Idaho Power Company in the study area, middle Snake River, southwestern Idaho

2. Summary of discharge measurements, associated measurement uncertainty, and estimated seepage gains or losses at selected reaches of the middle Snake River, southwestern Idaho, November 26-28, 2012

3. Summary of discharge measurements, associated measurement uncertainty, and estimated seepage gains or losses at selected reaches of the middle Snake River, southwestern Idaho, July 16-17, 2013

4. Summary of estimated seepage gains and losses for selected subreaches measured in the middle Snake River, southwestern Idaho, November 2012 and July 2013

5. Comparison discharge measurements made for quality assurance during seepage studies in the middle Snake River, southwestern Idaho, November 2012 and July 2013

6. Uncertainty estimates for discharge measurements and computed discharge at Adjusted Average Daily Flow thresholds and selected warning levels for four streamgages operated by Idaho Power Company, middle Snake River, southwestern Idaho, water years 2007-11. 


\section{Conversion Factors, Datums, and Abbreviations and Acronyms}

\section{Conversion Factors}

Inch/Pound to SI

\begin{tabular}{|c|c|c|}
\hline Multiply & By & To obtain \\
\hline \multicolumn{3}{|c|}{ Length } \\
\hline foot $(\mathrm{ft})$ & 0.3048 & $\operatorname{meter}(\mathrm{m})$ \\
\hline mile (mi) & 1.609 & kilometer (km) \\
\hline \multicolumn{3}{|c|}{ Area } \\
\hline acre & 4,047 & square meter $\left(\mathrm{m}^{2}\right)$ \\
\hline acre & 0.004047 & square kilometer $\left(\mathrm{km}^{2}\right)$ \\
\hline square mile $\left(\mathrm{mi}^{2}\right)$ & 259.0 & hectare (ha) \\
\hline square mile $\left(\mathrm{mi}^{2}\right)$ & 2.590 & square kilometer $\left(\mathrm{km}^{2}\right)$ \\
\hline \multicolumn{3}{|c|}{ Volume } \\
\hline acre-foot (acre-ft) & 1,233 & cubic meter $\left(\mathrm{m}^{3}\right)$ \\
\hline acre-foot (acre-ft) & 0.001233 & cubic hectometer $\left(\mathrm{hm}^{3}\right)$ \\
\hline \multicolumn{3}{|c|}{ Flow rate } \\
\hline acre-foot per day (acre-ft/d) & 0.01427 & cubic meter per second $\left(\mathrm{m}^{3} / \mathrm{s}\right)$ \\
\hline cubic foot per second $\left(\mathrm{ft}^{3} / \mathrm{s}\right)$ & 0.02832 & cubic meter per second $\left(\mathrm{m}^{3} / \mathrm{s}\right)$ \\
\hline $\begin{array}{l}\text { cubic foot per second per mile } \\
\qquad\left[\left(\mathrm{ft}^{3} / \mathrm{s}\right) / \mathrm{mi}\right]\end{array}$ & 0.01761 & $\begin{array}{l}\text { cubic meter per second per } \\
\text { kilometer }\left[\left(\mathrm{m}^{3} / \mathrm{s}\right) / \mathrm{km}\right]\end{array}$ \\
\hline \multicolumn{3}{|c|}{ Energy } \\
\hline megawatt (MW) & $1,000,000$ & Joules per second (J/s) \\
\hline
\end{tabular}

\section{Datums}

Vertical coordinate information is referenced to the North American Vertical Datum of 1988 (NAVD 88).

Horizontal coordinate information is referenced to the North American Datum of 1983 (NAD 83).

Elevation, as used in this report, refers to distance above the vertical datum

\section{Abbreviations and Acronyms}

$\begin{array}{ll}\text { ADCP } & \text { acoustic Doppler current profiler } \\ \text { ADV } & \text { acoustic Doppler velocimeter } \\ \text { COV } & \text { coefficient of variation } \\ \text { H-ADCP } & \text { Horizontal acoustic Doppler current profiler } \\ \text { IDWR } & \text { Idaho Department of Water Resources } \\ \text { MDT } & \text { Mountain Daylight Time } \\ \text { SFTWG } & \text { Swan Falls Technical Working Group } \\ \text { SRBA } & \text { Snake River Basin Adjudication } \\ \text { USGS } & \text { U.S. Geological Survey } \\ \text { WY } & \text { water year }\end{array}$





\title{
Evaluation of Seepage and Discharge Uncertainty in the Middle Snake River, Southwestern Idaho
}

\author{
By Molly S. Wood ${ }^{1}$, Marshall L. Williams' ${ }^{1}$, David M. Evetts' ${ }^{1}$, and Peter J. Vidmar ${ }^{2}$
}

\section{Abstract}

The U.S. Geological Survey, in cooperation with the State of Idaho, Idaho Power Company, and the Idaho Department of Water Resources, evaluated seasonal seepage gains and losses in selected reaches of the middle Snake River, Idaho, during November 2012 and July 2013, and uncertainty in measured and computed discharge at four Idaho Power Company streamgages. Results from this investigation will be used by resource managers in developing a protocol to calculate and report Adjusted Average Daily Flow at the Idaho Power Company streamgage on the Snake River below Swan Falls Dam, near Murphy, Idaho, which is the measurement point for distributing water to owners of hydropower and minimum flow water rights in the middle Snake River. The evaluated reaches of the Snake River were from King Hill to Murphy, Idaho, for the seepage studies and downstream of Lower Salmon Falls Dam to Murphy, Idaho, for evaluations of discharge uncertainty.

Computed seepage was greater than cumulative measurement uncertainty for subreaches along the middle Snake River during November 2012, the non-irrigation season, but not during July 2013, the irrigation season. During the November 2012 seepage study, the subreach between King Hill and C J Strike Dam had a meaningful (greater than cumulative measurement uncertainty) seepage gain of 415 cubic feet per second $\left(\mathrm{ft}^{3} / \mathrm{s}\right)$, and the subreach between Loveridge Bridge and C J Strike Dam had a meaningful seepage gain of $217 \mathrm{ft}^{3} / \mathrm{s}$. The meaningful seepage gain measured in the November 2012 seepage study was expected on the basis of several small seeps and springs present along the subreach, regional groundwater table contour maps, and results of regional groundwater flow model simulations.

\footnotetext{
${ }^{1}$ U.S. Geological Survey.

${ }^{2}$ Idaho Power Company.

${ }^{3}$ Hydropower water right Nos. 02-100, 02-2032A, 02-4000A, and 02-4001A are held by Idaho Power Company. Hydropower water right Nos. 02-4000B, 02-4001B, 02-2032B, 02-2036, 02-2056, 02-2065, 02-2064, 02-10135, 02-2060, 02-2059, 02-2001B, 02-2001A, 02-2057, 37-2128, 37-2472, 37-2471, 37-20710, 37-20709, 36-2013, 36-2018, and 36-2026 are held by the State of Idaho as trustee. Minimum flow water right Nos. 02-201, 02-223 and 02-224 are held by the Idaho Water Resource Board (State of Idaho; 2005, 2011a, 2011b, 2011c, 2014).
}

Computed seepage along the subreach from C J Strike Dam to Murphy was less than cumulative measurement uncertainty during November 2012 and July 2013; therefore, seepage cannot be quantified with certainty along this subreach.

For the uncertainty evaluation, average uncertainty in discharge measurements at the four Idaho Power Company streamgages in the study reach ranged from 4.3 percent (Snake River below Lower Salmon Falls Dam) to 7.8 percent (Snake River below C J Strike Dam) for discharges less than $7,000 \mathrm{ft}^{3} / \mathrm{s}$ in water years $2007-11$. This range in uncertainty constituted most of the total quantifiable uncertainty in computed discharge, represented by prediction intervals calculated from the discharge rating of each streamgage. Uncertainty in computed discharge in the Snake River below Swan Falls Dam near Murphy was 10.1 and 6.0 percent at the Adjusted Average Daily Flow thresholds of 3,900 and $5,600 \mathrm{ft}^{3} / \mathrm{s}$, respectively. All discharge measurements and records computed at streamgages have some level of uncertainty that cannot be entirely eliminated. Knowledge of uncertainty at the Adjusted Average Daily Flow thresholds is useful for developing a measurement and reporting protocol for purposes of distributing water to hydropower and minimum flow water rights in the middle Snake River.

\section{Introduction}

The State of Idaho has a need to determine flow, based on actual flow conditions but adjusted to remove fluctuations resulting from the operation of Idaho Power Company facilities, and to determine associated uncertainty in measured and computed discharge in the Snake River below Swan Falls Dam, near Murphy, Idaho (13172500; fig. 1), hereafter referred to as the "Murphy streamgage." Results from this investigation will be used by the State of Idaho in distributing water to owners of hydropower and minimum flow water rights as defined in State of Idaho (2005, 2011a, 2011b, and 2011c) ${ }^{3}$. The Swan Falls Technical Working Group (SFTWG) has been formed to develop a protocol for measuring, adjusting, and reporting average daily flow, hereafter referred to as "Adjusted Average Daily Flow," at the Murphy streamgage. Members of SFTWG include representatives from the Idaho Department of Water Resources (IDWR), the 


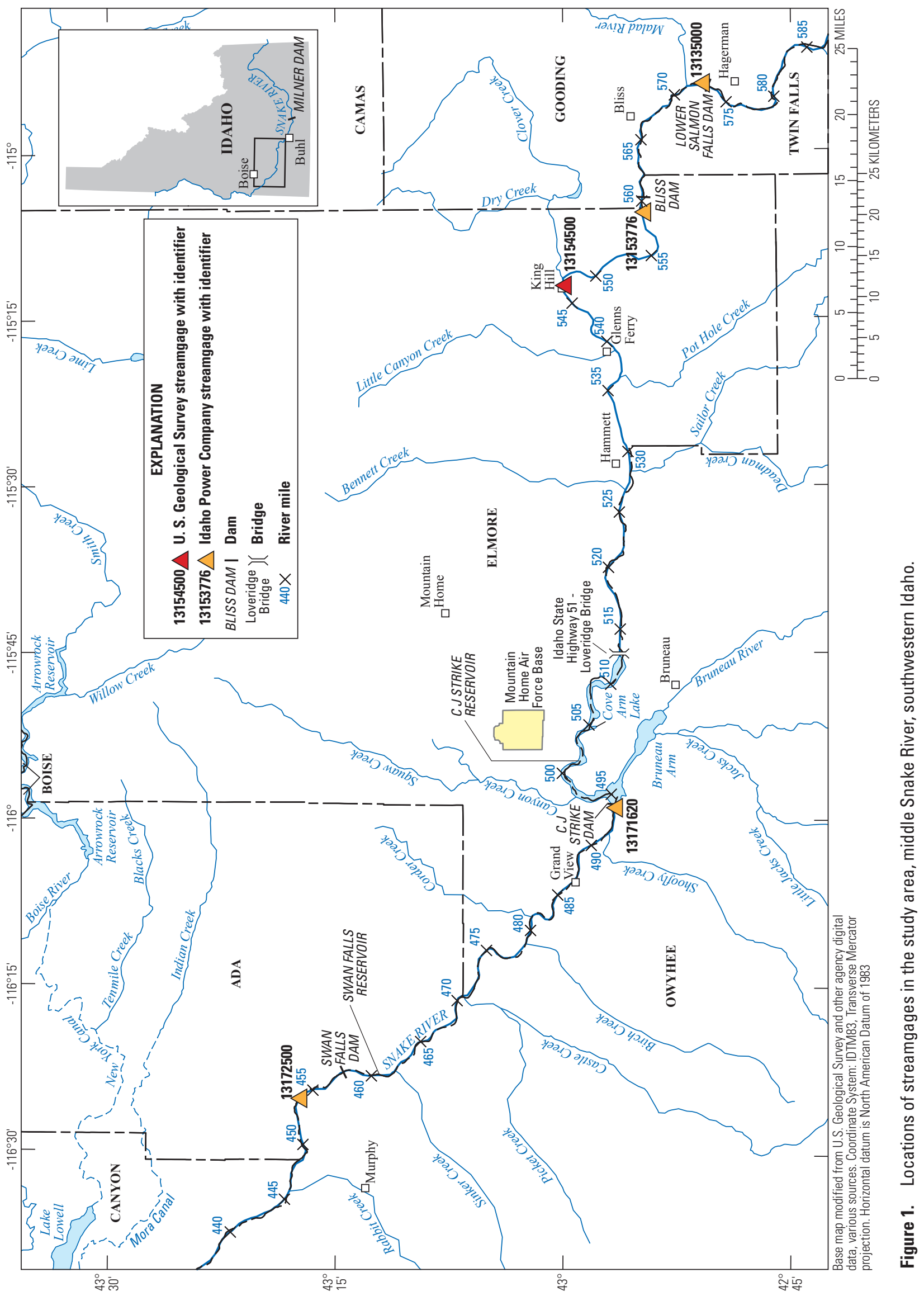


Idaho Power Company, and consulting engineers representing the State of Idaho, the city of Pocatello, and Idaho Ground Water Appropriators. The U.S. Geological Survey (USGS) is assisting the SFTWG by quantifying seepage gains and losses in the Snake River from King Hill, Idaho, to Murphy, Idaho, and estimating uncertainty in measured and computed discharge at Idaho Power Company streamgages on the Snake River from downstream of Lower Salmon Falls Dam near Hagerman, Idaho, to downstream of Swan Falls Dam near Murphy, Idaho. The term "flow" is used in some sections of this report where required to be consistent with terminology in State of Idaho (2005, 2011a, 2011b, and 2011c) and draft protocols developed by the SFTWG. The term "discharge" is used elsewhere to refer to all types of flow (computed and measured discharge in rivers, pipe diversions, inflows, outflows), following common USGS terminology used for reporting data on the National Water Information System (U.S. Geological Survey, 2014).

\section{Description of Partial Decrees for Water Rights in the Middle Snake River}

The Idaho Supreme Court issued an order establishing the Snake River Basin Adjudication (SRBA) in 1987 to identify and quantify water rights and to judicially settle related disputes in the Snake River Basin (State of Idaho, 2012, 2014). The court managing the SRBA has issued thousands of official decisions on water rights, called partial decrees, based on claims submitted since the inception of the SRBA. The SRBA court issues final decrees to water rights owners after all partial decree water rights have been reviewed and allocated and after related disputes have been resolved. The partial decrees entered in the SRBA for water rights in the study area described in this report provide for a minimum average daily flow of 3,900 ft $3 / \mathrm{s}$ from April 1 to October 31, and 5,600 $\mathrm{ft}^{3} / \mathrm{s}$ from November 1 to March 31 at the Murphy streamgage. Calculation of the Adjusted Average Daily Flow will be based on actual flow conditions, adjusted to account for fluctuations resulting from the operation of Idaho Power Company hydropower facilities in the Snake River (State of Idaho, 2011a, 2011b, 2011c, 2014). ${ }^{4}$

The partial decrees state that flows purchased, leased, owned or otherwise acquired by Idaho Power Company from sources upstream of its hydropower facilities, including those upstream of Milner Dam near Milner, Idaho (fig. 1), which are conveyed to hydropower facilities downstream of Milner

\footnotetext{
4"The term "Adjusted Average Daily Flow", as used herein, refers to the SFTWG proposed protocol for measuring and reporting average daily flow for purposes of distributing water to the hydropower and State minimum flow water rights decreed in State of Idaho (2011a, 2011b, 2011c and 2014). The partial decrees specify that for purposes of distribution of water to the decreed rights the "average daily flow...shall be based upon actual flow conditions... [and] any fluctuations resulting from the operation of Idaho Power Company facilities shall not be considered in the calculation of such flows" (State of Idaho, 2011a).
}

Dam (including facilities at Lower Salmon Falls, Bliss, C J Strike, and Swan Falls Dams; fig. 1), shall be considered fluctuations resulting from the operation of Idaho Power Company operations (State of Idaho; 2011a, 2011b, 2011c, 2014). The effects of such flows, therefore, will be considered in the calculation of the Adjusted Average Daily Flow at the Murphy streamgage for purposes of distributing water under the partial decrees. The partial decrees include provisions that exclude the Snake River upstream of Milner Dam (including contributions to the Snake River from tributary and groundwater inflows) from consideration in the distribution of water rights. Therefore, only the area in which groundwater and surface water are deemed tributary to the Snake River between Milner Dam and the Murphy streamgage can be considered for purposes of distribution of water to the partial decrees in the study area.

\section{Removal of Idaho Power Company Operations from Discharge Calculations}

The SFTWG is evaluating two methods for calculating an Adjusted Average Daily Flow for the middle Snake River, which accounts for (or removes) the effects of Idaho Power Company hydropower operations: (1) the "Reservoir-Stage Method", and (2) the "Flow Method". The Reservoir-Stage Method involves monitoring water levels in reservoirs along the study reach, calculating changes in reservoir storage using bathymetric surveys, incorporating wind effects on changes in reservoir stage and storage, and converting changes in reservoir storage to changes in discharge in the middle Snake River along the study reach. The Flow Method involves monitoring discharge into and out of each Idaho Power Company reservoir along the study reach, including all tributary inflows, irrigation diversions, and irrigation returns. A water budget then is developed for each reservoir to determine changes in discharge resulting from reservoir operations based on the Flow Method. The Reservoir-Stage and Flow Methods both require routing and then subtracting the calculated changes in discharge resulting from Idaho Power Company hydropower operations from the average daily discharge measured at the Murphy streamgage. River-channel seepage rates are needed if the Flow Method ultimately is selected by the SFTWG because they are a component of the water budget at each reservoir. The Reservoir-Stage Method ignores the seepage component because it assumes that the effects of any inflows or outflows, including seepage, pass unhindered to the Murphy streamgage; therefore, any changes in discharge resulting from changes in reservoir storage are owing only to Idaho Power Company hydropower operations. The ReservoirStage Method conceptually is more straightforward and easier to implement because it does not require a detailed, real-time accounting of all reservoir inflows and outflows. Regardless of which method is selected, uncertainty in the computed discharge is useful for developing a measurement and reporting protocol for use in distributing water for 
hydropower and the minimum flow water rights in accordance with the partial decrees and Idaho law. After installation of necessary monitoring equipment, the SFTWG plans to implement both the Reservoir-Stage and Flow Methods for an introductory period before recommending a method for future measurement and reporting of Adjusted Average Daily Flow at the Murphy streamgage.

\section{Purpose and Scope}

This report provides estimates of seepage in the middle Snake River during two seepage studies completed in November 2012 and July 2013. Additionally, the report provides estimates of uncertainty in discrete discharge measurements and computed discharge at four streamgages operated by Idaho Power Company in the middle Snake River for water years 2007-2011. Results from this investigation will be used by the SFTWG to determine the Adjusted Average Daily Flow, if the Flow Method is selected, and to determine the associated uncertainty in computed discharge at the Murphy streamgage. The study was conducted by the USGS in cooperation with the State of Idaho, Idaho Power Company, and the Idaho Department of Water Resources.

\section{Description of Study Area}

The Snake River flows from its headwaters in Wyoming near the southern border of Yellowstone National Park across the semiarid Snake River Plain in southern Idaho, ultimately flowing into the Columbia River near Pasco, Washington (not shown in fig. 1). The study area encompasses a 119-mi reach of the middle Snake River from Lower Salmon Falls Dam (13135000) to the Murphy streamgage (13172500) (fig. 1). Discharge measurements made as part of the seepage evaluation were limited to the reach between King Hill (13154500) and the Murphy streamgage (fig. 1); seepage was quantified previously for the reach between Milner Dam and King Hill in Hortness and Vidmar (2005). The middle Snake River in the reach between King Hill and the Murphy streamgage flows through an incised basalt canyon, as deep as $700 \mathrm{ft}$. Total drainage area at the Murphy streamgage is $41,900 \mathrm{mi}^{2}$. Underlying aquifers, consisting primarily of sedimentary materials and fractured basalts, discharge to the middle Snake River downstream of King Hill through springs and subsurface inflows. Groundwater in the study area generally moves toward the Snake River (Lindholm and others, 1988; Newton, 1991).

Flow in the middle Snake River along the study reach is highly regulated by dams that were constructed for hydropower generation, including Lower Salmon Falls, Bliss, C J Strike, and Swan Falls Dams (igg. 1) $)^{5}$. C J Strike

\footnotetext{
${ }^{5}$ Although the reservoirs were licensed for hydropower purposes rather than irrigation storage, some water is pumped for agricultural purposes.
}

Dam, at river mile 494.1 (fig. 1), creates the largest reservoir (C J Strike Reservoir) in the study reach, covering about 7,500 acres and storing about 247,000 acre-ft of water. Swan Falls Dam, at river mile 457.7 (fig. 1), impounds about 1,525 acres and stores 7,425 acre-ft of water. The hydropower facilities at these two dams have a combined maximum generating capacity of about 115 megawatts. Idaho Power Company operates four streamgages downstream of their hydropower facilities along the middle Snake River between river miles 453.5 and 572.5, downstream of Milner Dam: Snake River below Lower Salmon Falls Dam, near Hagerman, Idaho (13135000), below Bliss Dam, near Bliss, Idaho (13153776), below C J Strike Dam, near Grand View, Idaho (13171620), and below Swan Falls Dam, near Murphy, Idaho (13172500) (fig. 1, table 1). River miles are referenced upstream of the Snake River confluence with the Columbia River. These streamgages were operated by the USGS until 2001, when ownership was transferred to Idaho Power Company (table 1). The four streamgages are operated under the supervision of, and in cooperation with, the USGS in accordance with Federal Energy Regulatory Commission dam-licensing requirements. This cooperative effort between Idaho Power Company and the USGS helps ensure that discharge measurements and reporting meet USGS standard protocols that are documented in Rantz (1982), Mueller and Wagner (2009), Sauer and Turnipseed (2010), Turnipseed and Sauer (2010), Levesque and Oberg (2012), and various USGS policy memorandums. Additionally, the USGS operates a streamgage on the Snake River at King Hill (streamgage site 13154500) (fig. 1), which allows hydrographic comparison with streamgages operated by Idaho Power Company in the study reach.

Numerous gravity-flow and pumped water diversions are present in the study reach for irrigation and agricultural use. Many of these diversions supply water to croplands above the canyon on the western Snake River Plain. Discharge in the middle Snake River during irrigation season is altered substantially by irrigation diversions and return flow (unconsumed irrigation water that returns to the river through drains or groundwater seepage; Hortness and Vidmar, 2005).

\section{Previous Investigations}

Studies have described the hydrogeology of the regional aquifer system in southwestern Idaho, also referred to as the western Snake River Plain aquifer system. Some of these hydrogeological studies (including Kjelstrom, 1986; Lindholm and others, 1988; and Newton, 1991) were completed as part of the USGS Regional Aquifer-System Analysis Program, starting in the late 1970s following a congressional mandate to develop quantitative assessments of major groundwater systems in the United States. Several other studies (including Ralston and Chapman, 1968; Norton and others, 1982; and 
Table 1. Streamgages operated by Idaho Power Company in the study area, middle Snake River, southwestern Idaho.

[See figure 1 for site locations. Latitude and longitude: In degrees, minutes, and seconds. River mile: Referenced as distance upstream of the mouth of the Snake River at its confluence with the Columbia River in Washington. Abbreviations: mi, mile; USGS, U.S. Geological Survey; IPCo, Idaho Power Company]

\begin{tabular}{|c|c|c|c|c|c|c|}
\hline Site No. & Site name & Latitude & Longitude & $\begin{array}{l}\text { River } \\
\text { mile }\end{array}$ & $\begin{array}{l}\text { Location relative } \\
\text { to dam }\end{array}$ & $\begin{array}{c}\text { Period of } \\
\text { discharge record }\end{array}$ \\
\hline 13135000 & $\begin{array}{l}\text { Snake River below Lower } \\
\text { Salmon Falls Dam, near } \\
\text { Hagerman, Idaho }\end{array}$ & $42^{\circ} 50^{\prime} 55^{\prime \prime}$ & $114^{\circ} 54^{\prime} 05^{\prime \prime}$ & 572.5 & $\begin{array}{l}0.5 \text { mi downstream of } \\
\text { Lower Salmon Falls } \\
\text { Dam }\end{array}$ & $\begin{array}{l}\text { October } 1937 \text { to March } 2001 \text { (USGS); } \\
\text { April } 2001 \text { to present (IPCo) }\end{array}$ \\
\hline 13153776 & $\begin{array}{l}\text { Snake River below Bliss } \\
\text { Dam, near Bliss, Idaho }\end{array}$ & $42^{\circ} 54^{\prime} 52^{\prime \prime}$ & $115^{\circ} 05^{\prime} 36^{\prime \prime}$ & 559.3 & $\begin{array}{l}1.0 \text { mi downstream of } \\
\text { Bliss Dam }\end{array}$ & $\begin{array}{l}\text { August } 1991 \text { to March } 2001 \text { (USGS); } \\
\text { April } 2001 \text { to present (IPCo) }\end{array}$ \\
\hline 13172500 & $\begin{array}{l}\text { Snake River below Swan } \\
\text { Falls Dam, near Murphy, } \\
\text { Idaho }\end{array}$ & $43^{\circ} 17^{\prime} 31^{\prime \prime}$ & $116^{\circ} 25^{\prime} 15^{\prime \prime}$ & 453.5 & $\begin{array}{l}4.2 \text { mi downstream of } \\
\text { Swan Falls Dam }\end{array}$ & $\begin{array}{l}\text { August to October 1912, August } 1913 \\
\text { to July } 2001 \text { (USGS); } \\
\text { July } 2001 \text { to present (IPCo) }\end{array}$ \\
\hline
\end{tabular}

Bendixsen, 1994) were completed as part of an effort to assess and protect "critical groundwater areas" in danger of overdevelopment and potential overappropriation of water resources near Mountain Home, Idaho (fig. 1). The studies indicated regional movement of groundwater to the Snake River from various aquifers consisting of fractured basalt and intervening fine-grained sediment and gravels (Ralston and Chapman, 1968; Newton, 1991).

A 1988 contour map of the groundwater table by Lindholm and others (1988) shows a steep gradient of groundwater movement to the Snake River in the reach from Milner Dam to King Hill, then a more gentle gradient from King Hill to Murphy. Hortness and Vidmar (2005) measured a meaningful (greater than cumulative measurement uncertainty) net gain in seepage from groundwater to surface water in the reach between Milner Dam and King Hill in 2001-02: an average gain of 4,690 ft3 $3 / \mathrm{s}$ in November 2001-02 and a gain of $4,570 \mathrm{ft}^{3} / \mathrm{s}$ in July 2002. Hortness and Vidmar (2005) noted that nearly all the seepage in this reach occurred upstream of Lower Salmon Falls Dam and that the highest seepage rate was measured in the reach between Buhl and Lower Salmon Falls Dam (fig. 1), around the Thousand Springs Complex (not shown in fig. 1). Using a groundwater model, Newton (1991) estimated a gain in seepage of $461 \mathrm{ft}^{3} / \mathrm{s}$ from groundwater to surface water in the reach between King Hill and Murphy. The gain in seepage estimated by Newton (1991) was about 4 percent of the average annual discharge of the Snake River at the Murphy streamgage.

Quantitative analyses of measurement and discharge-record uncertainty have not been completed in the past, although Idaho Power Company and the USGS typically have rated the published records of average daily discharge at the Murphy streamgage as "good." A "good" rating indicates that 95 percent of the computed average daily discharges are within 10 percent of the true value (Kennedy, 1983). The rating assigned to published records is a subjective determination based on the quality, number, and range of measurements, quality and stability of the relation between stage and discharge, and other factors.

\section{Seepage Evaluation}

Seepage along the middle Snake River was evaluated during two periods: November 26-28, 2012, non-irrigation season, and July 16-17, 2013, irrigation season, to supply information to the SFTWG for the calculation of Adjusted Average Daily Flow at the Murphy streamgage. Irrigation season for the study area typically is April to October. The reach evaluated during the November 2012 seepage study was a 93.1-mile reach between the streamgages at King Hill (main-stem site 1) and Murphy (main-stem site 19) (fig. 2), and included 60 measurement sites measured over 3 days. The reach evaluated during the July 2013 seepage study was a 65.5-mile reach, from main-stem site 4 to 19 (fig. 3), and included 109 measurement sites (including 41 irrigation water diversions discharging through pumps and pipes) measured over 2 days. The sample reach was selected for the July 2013 seepage study (1) to focus on an area of interest to the SFTWG around the two largest reservoirs in the study reach, C J Strike and Swan Falls Reservoirs (figs. 1- ); and (2) because the irrigation diversion and return flow system between main-stem sites 1 and 4 was too complex to measure given time constraints. 


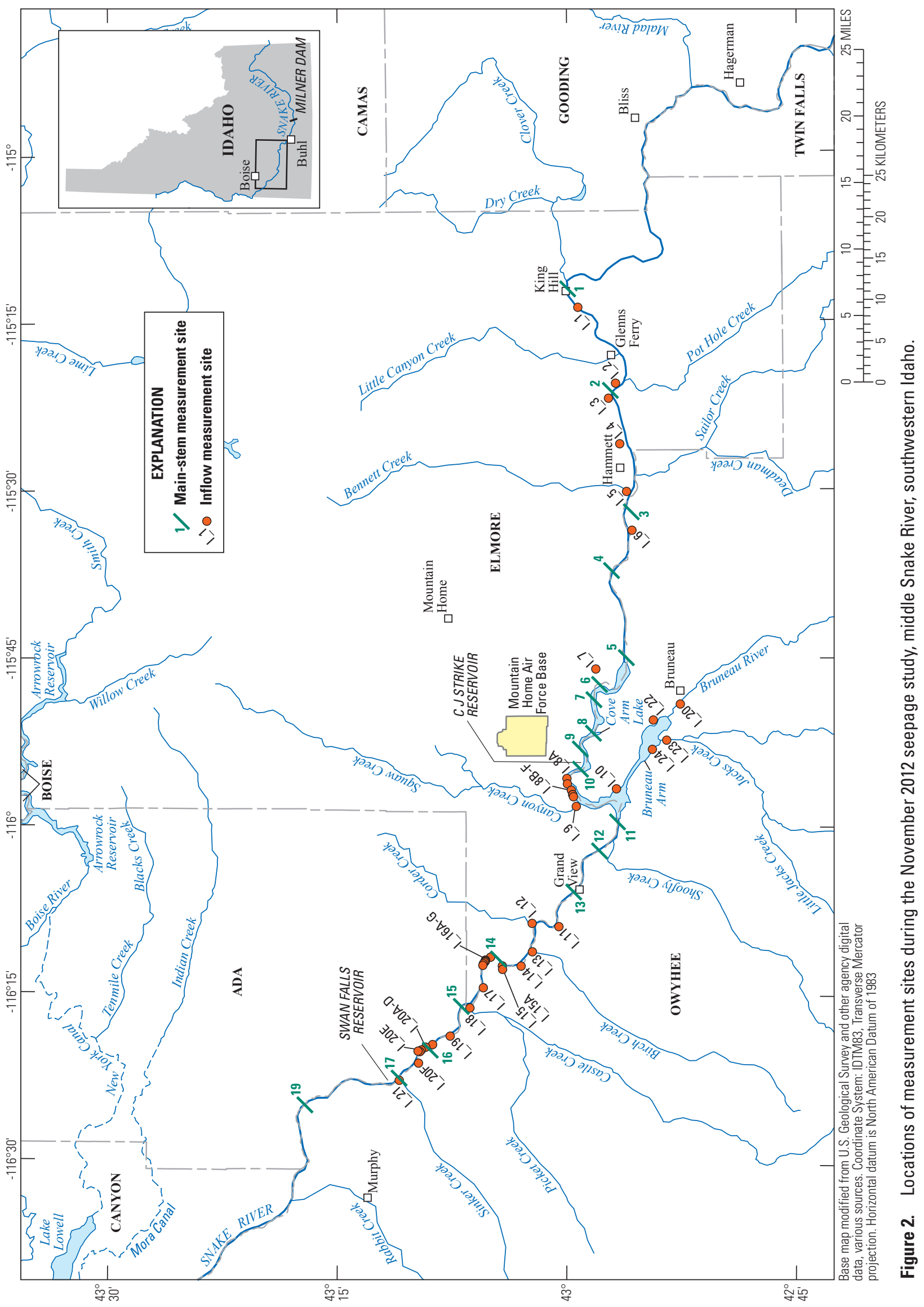




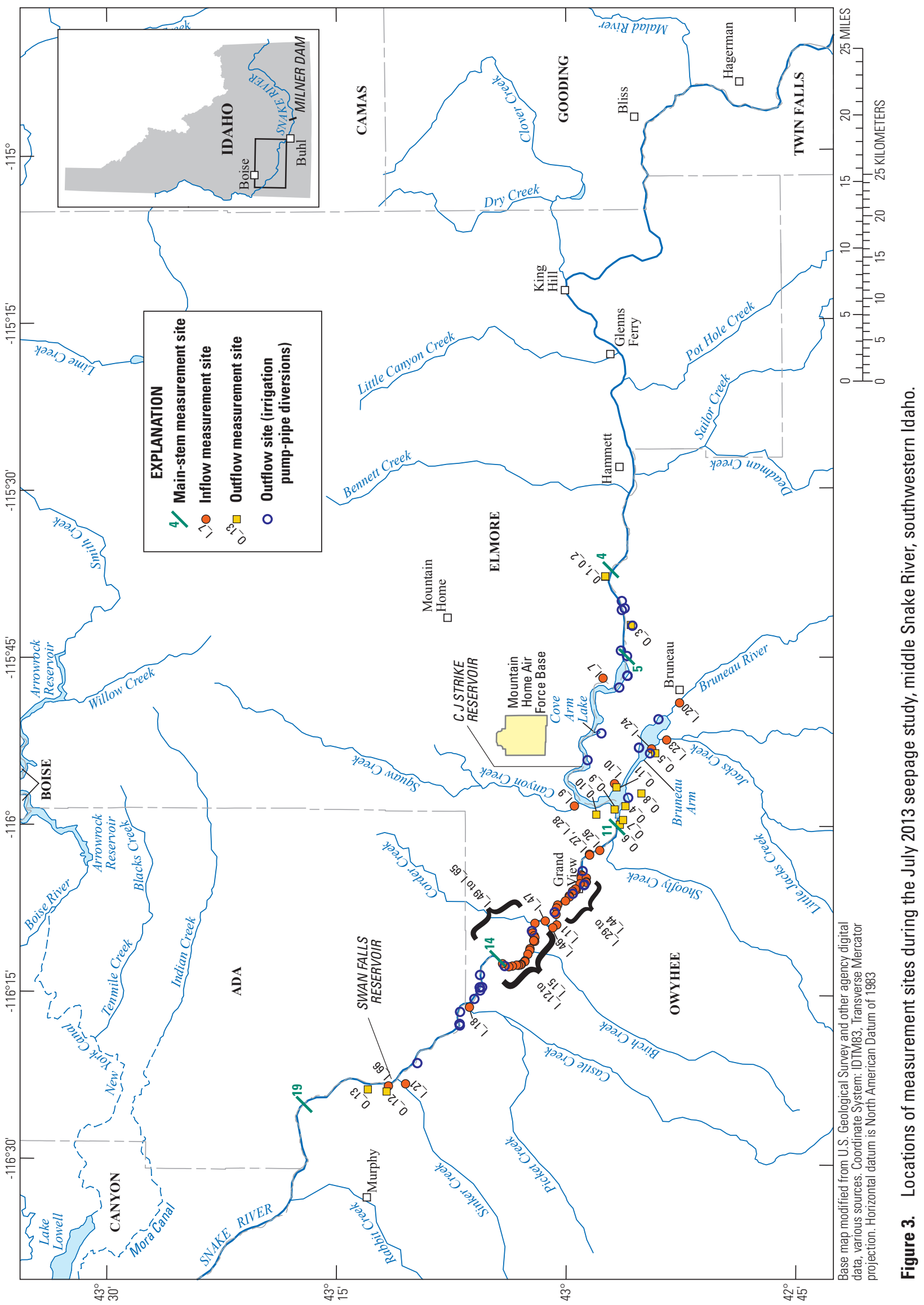




\section{Methods for Estimating Seepage}

Seepage was calculated by making a series of discharge measurements, assigning uncertainty to each measurement, calculating a water mass balance for individual reaches, and attributing the water remaining from the mass balance to a seepage gain or loss from groundwater to surface water. The calculated seepage gain or loss for a given reach was considered meaningful if it was greater than the cumulative measurement uncertainty for that reach.

\section{Discharge Measurements for Calculating Seepage}

To calculate seepage, discharge measurements were made by teams of USGS, IDWR, and Idaho Power Company personnel. Measurements were made at sites on the main stem middle Snake River and at any inflows (tributaries, springs, and irrigation returns and drains) or outflows (diversion canals, pumps, and pipes) between main-stem sites (figs. 2 and $\underline{3}$ ). At least one USGS employee was present on each measurement team for the main-stem sites and most of the inflow and outflow sites. All measurements were reviewed by USGS personnel to ensure compliance with USGS policies. Discharge measurements were made using acoustic Doppler current profilers (ADCPs) (all main-stem sites and some inflows and outflow sites) deployed from inflatable kayaks (fig. 4) or acoustic Doppler velocimeters (ADVs) (some inflow and outflow sites) deployed on top-setting rods while wading the channel. Quality assurance tests of all ADCPs were done at the New York Canal near Boise, Idaho (igs. 1- $\underline{3}$ ) on October 31, 2012, and July 10, 2013, prior to the seepage studies in November 2012 and July 2013, respectively, to ensure that the ADCPs produced accurate results prior to their use in each study.

During the seepage studies, all discharge measurements at main-stem sites were made with the same model and frequency of ADCP, a Teledyne RD Instruments 1200-kiloHertz (kHz) Rio Grande ADCP, to reduce uncertainty resulting from a change in instrumentation. Any bias owing to use of a particular brand of instrument, if present, was assumed to be constant between measurement sites and would be inconsequential because only the net difference in discharge measurement was of interest. One exception was made at main-stem site 3 (fig. 2), where depths were too shallow to be measured by the

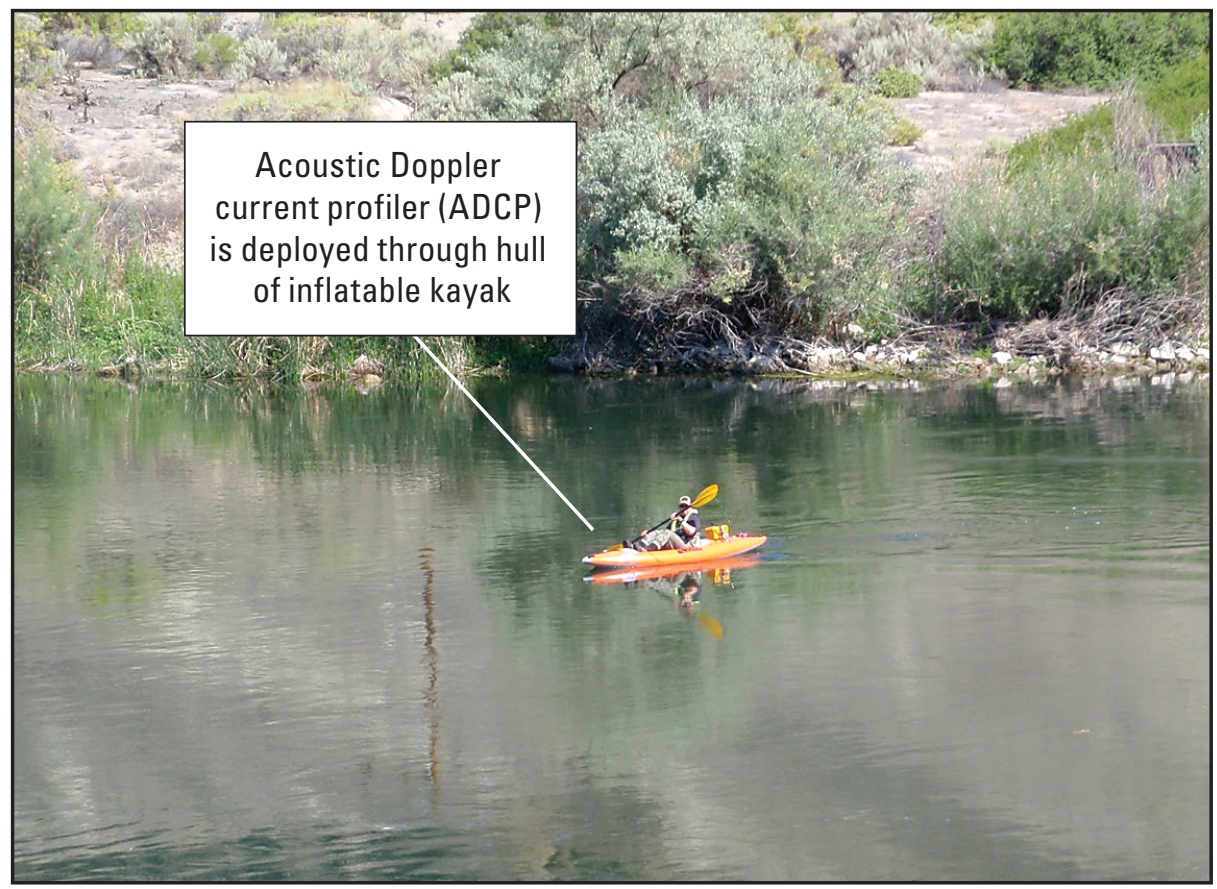

Figure 4. Measurement of discharge with an acoustic Doppler current profiler deployed in an inflatable kayak at main-stem site 14, middle Snake River, southwestern Idaho. Photograph taken by Michael Campbell, Idaho Power Company, July 16, 2013. 
Rio Grande ADCP, so the site instead was measured with a SonTek RiverSurveyor ${ }^{\circledR}$ M9 ADCP. Measurements were made and processed following USGS procedures described in Mueller and Wagner (2009) and Turnipseed and Sauer (2010), except that each main stem measurement consisted of 12 transects (directional passes across the river) to increase exposure time (length of time the ADCP was measuring and representing conditions) and to reduce the overall random uncertainty in measurements.

Water depth or discharge in some inflows was too small to be measured using an ADCP or ADV. Measurement teams estimated discharge at these sites based on observations of channel areas and water velocities, a combination of observations and limited (1-to-5) point velocities measured with an $\mathrm{ADV}$, or timed volume calculations made by collecting and measuring a volume of flowing water over time. Measurement teams also observed several inflows with channels that were dry or had ponded water, which were estimated to have zero discharge.

During the November 2012 seepage study, discharge measurements were made at 18 main-stem sites and 42 inflow sites (fig. 2). Each main-stem measurement in the November 2012 seepage study consisted of a single set of 12 transects, and each measurement crew visited multiple sites. Eight comparison discharge measurements were made at six main-stem sites during the November 2012 seepage study, immediately before or after the primary discharge measurement, using a SonTek RiverSurveyor ${ }^{\circledR}$ M9 ADCP. The comparison measurements were made to check that the ADCPs were producing consistent results and to assess ADCP instrument manufacturing bias.

During the July 2013 seepage study, discharge measurements were made at 5 main-stem sites, 50 inflow sites, and 54 outflow sites (13 ADCP measurement sites and 41 irrigation pump-pipe diversions; fig. 3). Logistics for the July 2013 seepage study differed from the November 2012 seepage study in that measurement crews were stationed at a single main-stem site and made a series of 12 transect measurements over a 4- to 8-hour period, with measurement times staggered in an effort to account for time of travel between sites and to enable measuring the "same" parcel of water at other downstream sites measured on the same day. Additionally, eight comparison discharge measurements were made at all five main-stem and three outflow sites during the July 2013 seepage study using a SonTek RiverSurveyor ${ }^{\circledR}$ M9 ADCP (for main-stem sites) or Teledyne RD Instruments $2000 \mathrm{kHz}$ StreamPro ADCP (for outflow sites), and were compared to the primary discharge measurements. Outflow discharge in 41 irrigation water (pump-pipe) diversions was measured by IDWR personnel during the July 2013 seepage study using General Electric Panametrics Ultrasonic flow meters with model number 402, 1 megaHertz transducers. The measurement results and uncertainty estimates were provided to the USGS for inclusion in the seepage calculations.

\section{Discharge Measurement Uncertainty}

Each discharge measurement used in calculating seepage was assigned an uncertainty estimate, which was calculated in different ways depending on the instrument used to make the measurement. The SonTek FlowTracker ${ }^{\circledR}$ ADV calculated random uncertainty internally through a statistical technique developed by the USGS and output a statistical uncertainty value as a percentage at the completion of a measurement (called "Stats" uncertainty in the SonTek FlowTracker ${ }^{\circledR}$ software). The Stats uncertainty calculated by the FlowTracker ${ }^{\circledR}$ software was used as the random uncertainty for discharge measurements made using a SonTek FlowTracker ${ }^{\circledR}$ ADV. Further description of the Stats uncertainty calculation for the SonTek FlowTracker ${ }^{\circledR}$ ADV is available from SonTek/Yellow Springs Instruments (2009).

Assessing uncertainty in ADCP measurements was partially subjective. Random uncertainty was objectively determined by multiplying the coefficient of variation (COV) of the measurement, which is output by the ADCP software, by a factor based on a 95-percent confidence level t-statistic and the number of transects in the measurement (equation 1, adapted from Williams, 2011):

Random uncertainty in discharge measurements $=$

$$
\operatorname{Cov} \times\left(t \frac{\alpha}{2} / \sqrt{n}\right)
$$

where

$\mathrm{COV}$ is the coefficient of variation of the measurement, in percent;

$t \frac{\alpha}{2}$ is determined from a $t$ distribution with degrees of freedom equal to the number of $\operatorname{transects}(n)-1$;

$n$ is the number of transects in the measurement; and

$\alpha$ is the confidence level, in the term $t \frac{\alpha}{2}$.

Additional uncertainty was added to the random uncertainty based on systematic (instrument) uncertainty and a subjective evaluation based on professional assessment of extrapolation methods, percent of estimated discharge, percent and location of invalid data, consistency in edge discharges, and the quality of data collected to correct for moving bed, if present. Systematic uncertainty represents a base uncertainty specification common to all ADCPs used in the study and is estimated at 0.5 percent based on information provided by ADCP manufacturers (David Mueller, U.S. Geological Survey Office of Surface Water, written commun., 2012). Total uncertainty for a discharge measurement was calculated as random uncertainty plus systematic uncertainty plus additional uncertainty determined from professional assessment. 
The term $\left(t \frac{\alpha}{2} / \sqrt{n}\right)$ in equation 1 is reduced when the number of transects measured is increased. For example, at a 95-percent confidence level, the rounded value for the term $\left(t \frac{\alpha}{2} / \sqrt{n}\right)$ is 1.6 for 4 transects, 1.1 for 6 transects, 0.8 for 8 transects, and 0.6 for 12 transects (David Mueller, U.S. Geological Survey Office of Surface Water, written commun., 2011). Policy in U.S. Geological Survey (2011) states that ADCP discharge measurements made during steady-flow conditions must have a minimum duration of 12 minutes and consist of at least two transects collected in opposite directions across the stream channel. Collecting eight or more transects can decrease the random uncertainty in discharge measurements to less than the COV and is desirable when trying to increase the precision of measurements at low discharge. Collecting more transects than the required minimum, however, does not decrease any bias (non-random uncertainty) in discharge measurements that might be associated with a particular measurement platform or instrument, an improper extrapolation of discharge in unmeasured areas, and other factors.

An example of the measurement uncertainty calculation is provided for a discharge measurement made at main-stem site 11 on July 16, 2013, at 8:39 a.m. Mountain Daylight Time (MDT) (equation 2). Twelve transects were collected, so the factor representing a t-statistic at a 95-percent confidence level ( $\alpha=0.025$, two-tailed probability) and the number of transects is 0.6 (David Mueller, U.S. Geological Survey Office of Surface Water, written commun., 2011). The COV for the measurement was 2.0 percent. Non-random uncertainty was added to the random uncertainty (1.2 percent) to account for systematic uncertainty ( 0.5 percent) and the variability in computed discharge observed when applying various, statistically appropriate extrapolation methods to estimate discharge in unmeasured areas at the top and bottom of the water column (1.0 percent). Total estimated uncertainty for this measurement is 2.7 percent.

Total uncertainty $=$ Random uncertainty + sytematic uncertainty + additional uncertainty

Total uncertainty $=\left[\operatorname{COV} \times\left(t \frac{\alpha}{2} / \sqrt{n}\right)\right]+0.5$ + additional uncertainty

Total uncertainty $=[2.0 \times 0.6]+0.5+1.0=2.7$ percent

\section{Seepage Calculations}

Seepage was calculated from discharge measurements made at sites along the main stem of the river, and at inflows and outflows between main-stem sites. The increase or decrease in discharge between main-stem sites that cannot be attributed to inflows or outflows represents the net seepage between groundwater and surface water, and is calculated according to equation 3 adapted from Simonds and Sinclair (2002):

$$
\text { Net seepage gain or loss }=Q_{d}-I-Q_{u}+O+\Delta S
$$

where

$Q_{d}$ is the discharge measured at the
downstream end of the reach, in cubic feet per second;

$I$ is the sum of inflows from tributaries, springs, or irrigation returns, in cubic feet per second;

$Q_{u}$ is the discharge measured at the upstream end of the reach, in cubic feet per second;

$O$ is the sum of the outflows from canals or irrigation diversions, in cubic feet per second; and

$\Delta S$ is the rate of change in storage of water in the reach, in cubic feet per second.

The change in storage term is disregarded in reaches without storage and when reservoir water levels indicate constant storage. The calculated net seepage is the estimated volumetric rate of water gained or lost from the river. Positive values indicate movement of water from groundwater to surface water, and negative values indicate movement of water from surface water to groundwater. Losses from evaporation were not included in the seepage calculations. Evaporation rates were estimated for the study area based on pan evaporation measurements published by the Western Regional Climate Center (2014) at Minidoka Dam on the Snake River (not shown on fig. 1), about $100 \mathrm{mi}$ upstream of the upstream extent of the study area. Evaporation rate estimates were substantially smaller than discharge measurement uncertainty and were considered negligible for this study over periods when seepage was calculated (maximum of 4-6 hours between measurement sites).

Dam operators were expected to maintain relatively constant releases from their facilities on a given day during the November 2012 and July 2013 seepage studies, so seepage 
was calculated only for subreaches of the middle Snake River measured on the same day to avoid errors associated with changes in releases among days. As noted in section, "Discharge Measurements for Calculating Seepage," discharge was measured at main-stem sites during the July 2013 seepage study using a series of 12-transect measurements made continuously over a 4- to 8-hour period. Measurements were selected for calculation of seepage between sites in different ways for the two days of the July 2013 seepage study:

- On July 16, discharge was measured in the reach between main-stem sites 11 and 19. Reservoir levels were held fairly constant in C J Strike and Swan Falls Reservoirs during the measurement period on July 16 , but discharge fluctuations occurred on this day (1) because of changes in discharge upstream of the study reach, which were translated through and released out of the reservoirs; or (2) because of changes in withdrawals at diversion points, most of which were measured and accounted for in the seepage calculations. As a result, comparison measurements were selected to represent an approximate time of travel between measurement sites so that the same parcel of water might be compared. A 4-hour travel time was assumed between each site based on an Idaho Power Company 8-hour estimate of travel time between main-stem sites 11 and 19 (Jon Bowling, Idaho Power Company, written commun., 2013). The seepage estimates for July 16 were determined using the first measurement at main-stem site 11 (average time 9:00 a.m. MDT), the fourth measurement at main-stem site 14 (average time 12:30 p.m. MDT), and the third measurement at mainstem site 19 (average time 16:40 p.m. MDT) (fig. 5).
A sensitivity analysis was done to determine whether seepage results differed depending on which logical combination of measurements among the three sites was selected.

- On July 17 , discharge measurements were made in the reach between main-stem sites 4 and 11. Measured discharges were relatively steady at main-stem sites 4 and 5, but discharge records from C J Strike Dam turbines indicated that the discharge from the dam decreased starting mid-day (fig. 5), resulting in an increase in reservoir storage. As a result, a change in storage term was included in the seepage calculations for July 17. The seepage estimates for July 17 were determined by averaging all measurements made at main-stem sites 4 and 5 . The last three measurements at main-stem site 11 were made when discharge steadied after the change in storage (fig. 5). USGS and Idaho Power Company personnel reviewed storage changes in C J Strike Reservoir during the period and determined that the rate of fill was about 800 acre- $\mathrm{ft} / \mathrm{d}$ or $403 \mathrm{ft} 3 / \mathrm{s}$. As a result, the average of all measurements made at main-stem site 5 was compared to the average of the last three measurements made at main-stem site 11, and a change in storage term of $403 \mathrm{ft}^{3} / \mathrm{s}$ was included in the seepage calculation between the two sites.

The total seepage estimated for a particular reach was compared to the cumulative uncertainty of the measurements used in the seepage calculation, calculated according to equation 4 adapted from Williams (2011), to determine if seepage was meaningful:

$$
C U=\sqrt{\left( \pm U_{u}\right)^{2}+\left( \pm U_{d}\right)^{2}+\left( \pm U_{I_{1}}\right)^{2} \ldots+\left( \pm U_{I_{n}}\right)^{2}+\left( \pm U_{O_{1}}\right)^{2} \ldots+\left( \pm U_{O_{n}}\right)^{2}}
$$

where

$C U$ is the cumulative measurement uncertainty for a reach,

$U_{u}$ is the uncertainty for the measurement made at the upstream end of the reach,

$U_{d}$ is the uncertainty for the measurement made at the downstream end of the reach,

$U_{I_{1}} \ldots U_{I_{n}}$ are the uncertainties for measurements made at any inflows along the reach, and

$U_{O_{1}} \ldots U_{O_{n}}$ are the uncertainties for measurements made at any outflow along the reach. 


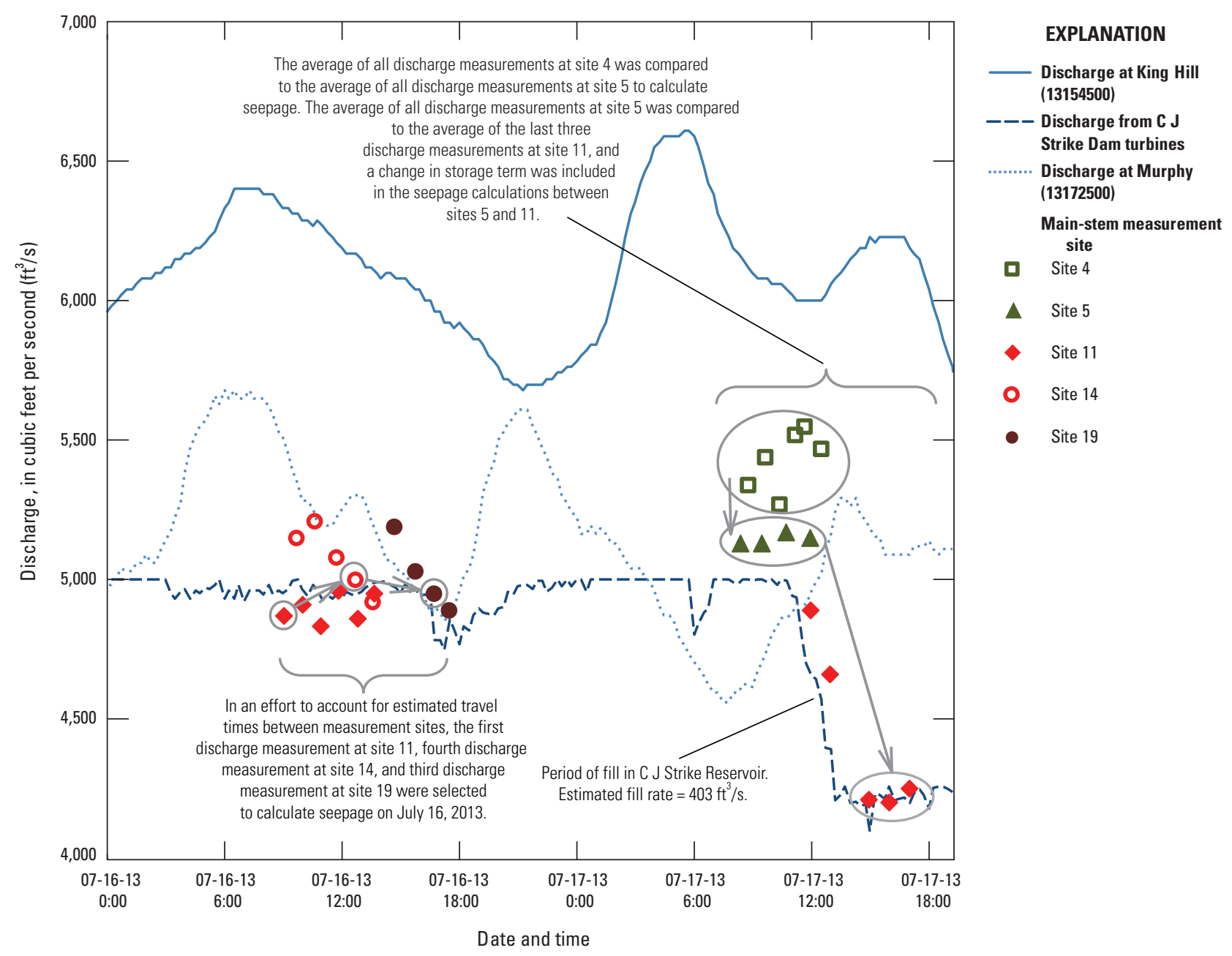

Figure 5. Discharge measurements selected and grouped for calculation of seepage in the middle Snake River, southwestern Idaho, July 16-17, 2013.

\section{Seepage Estimates}

Average discharge was $6,850 \mathrm{ft}^{3} / \mathrm{s}$ at King Hill (13154500) and 7,100 $\mathrm{ft}^{3} / \mathrm{s}$ at Murphy (13172500) streamgages during the November 2012 seepage study, and $6,070 \mathrm{ft}^{3} / \mathrm{s}$ at King Hill and 5,140 $\mathrm{ft}^{3} / \mathrm{s}$ at Murphy streamgages during the July 2013 seepage study. Seepage in the study reach was expected to be less than seepage measured by Hortness and Vidmar (2005) in the reach from Milner Dam to King Hill based on groundwater contours published in Lindholm and others (1998) and due to fewer springs and seeps along the river between the King Hill and Murphy streamgages compared to the upstream reach.

\section{November 2012 Seepage Study}

Net seepage gains and losses greater than measurement uncertainty were measured in four reach segments during the November 2012 seepage study (table 2, fig. 6). A net seepage gain was computed between main-stem sites 2 and 3 .
Several springs and seeps were noted near main-stem site 2, and the river canyon narrows in this area, which might indicate a change in geology and increased exchange between groundwater and surface water. As noted in section, "Methods for Estimating Seepage," the measurement of discharge at main-stem site 3 was made with a different ADCP than was used on other main stem measurements because of depth limitations. Seepage calculations for the reaches between mainstem sites 2 and 3 , and 3 and 4 might be affected slightly by the use of a different ADCP at main-stem site 3, but overall, no consistent bias was detected among instruments during comparison measurements at other sites. The reach between main-stem sites 3 and 4 showed a net seepage loss. The Snake River is braided in this area and might exchange water readily with sediments in the islands and in the braided channel, which might explain the measured loss. A net seepage gain was measured between main-stem sites 4 and 5. No springs were noted along this reach, but several marshes are present along the riverbanks, and the river channel is braided. 


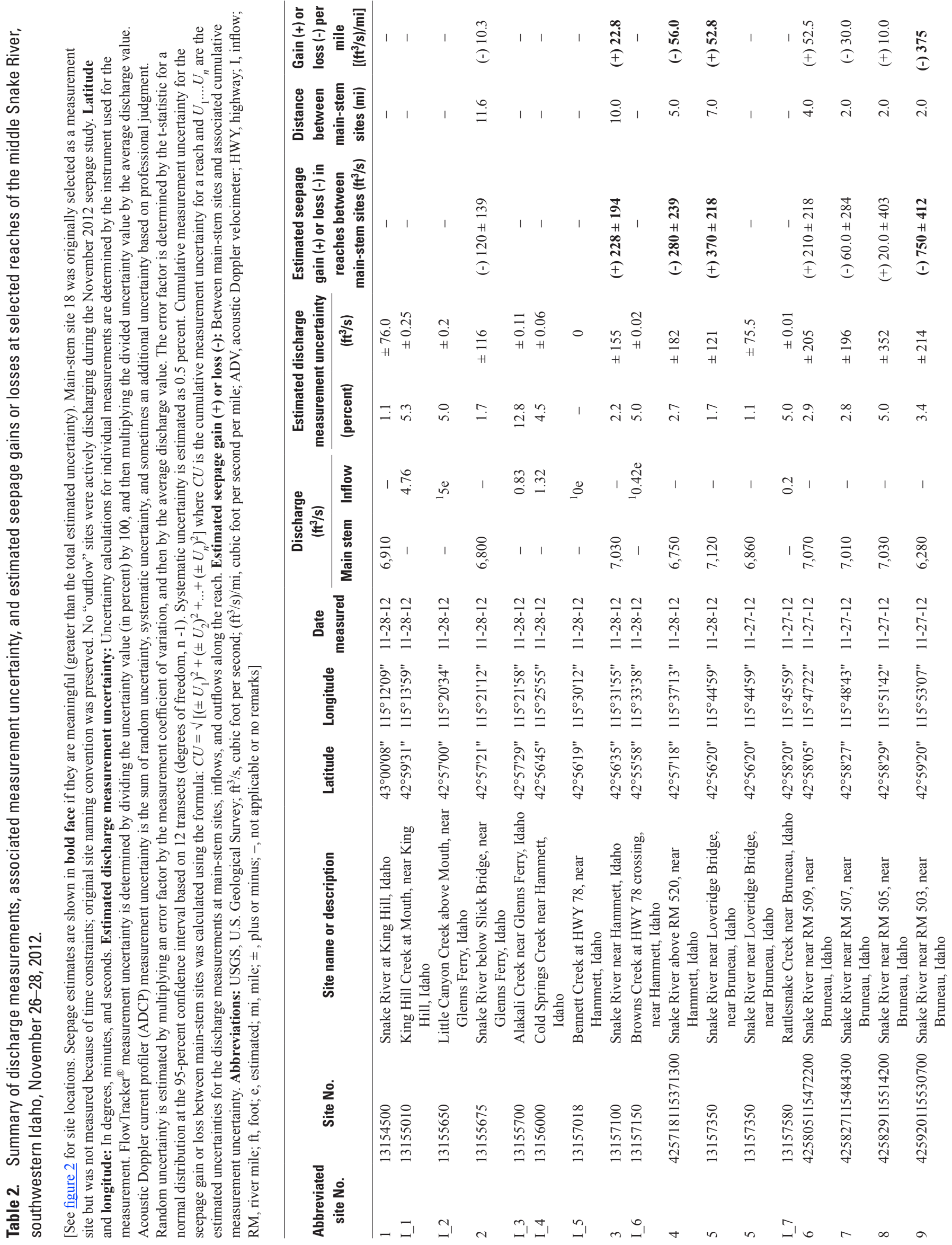




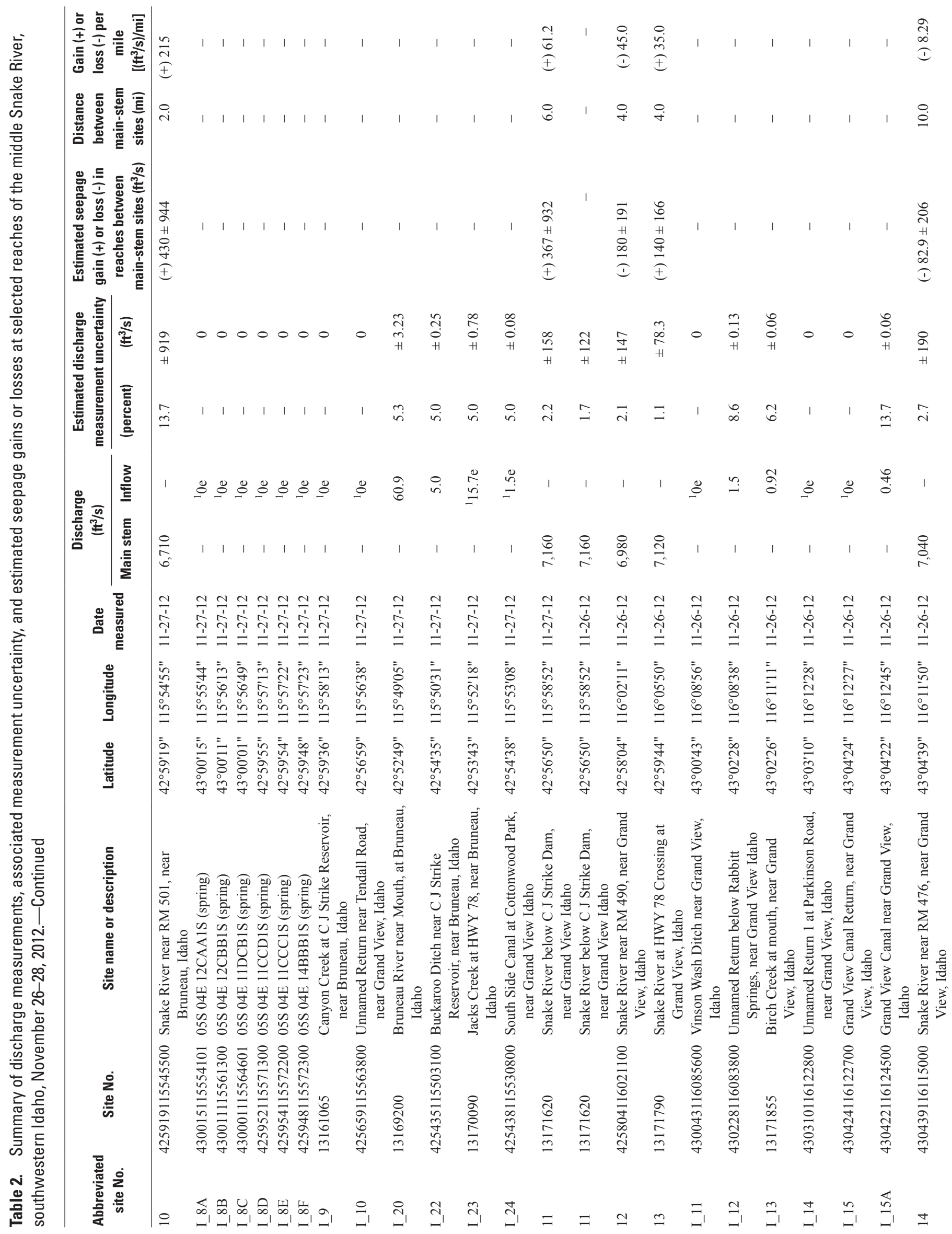




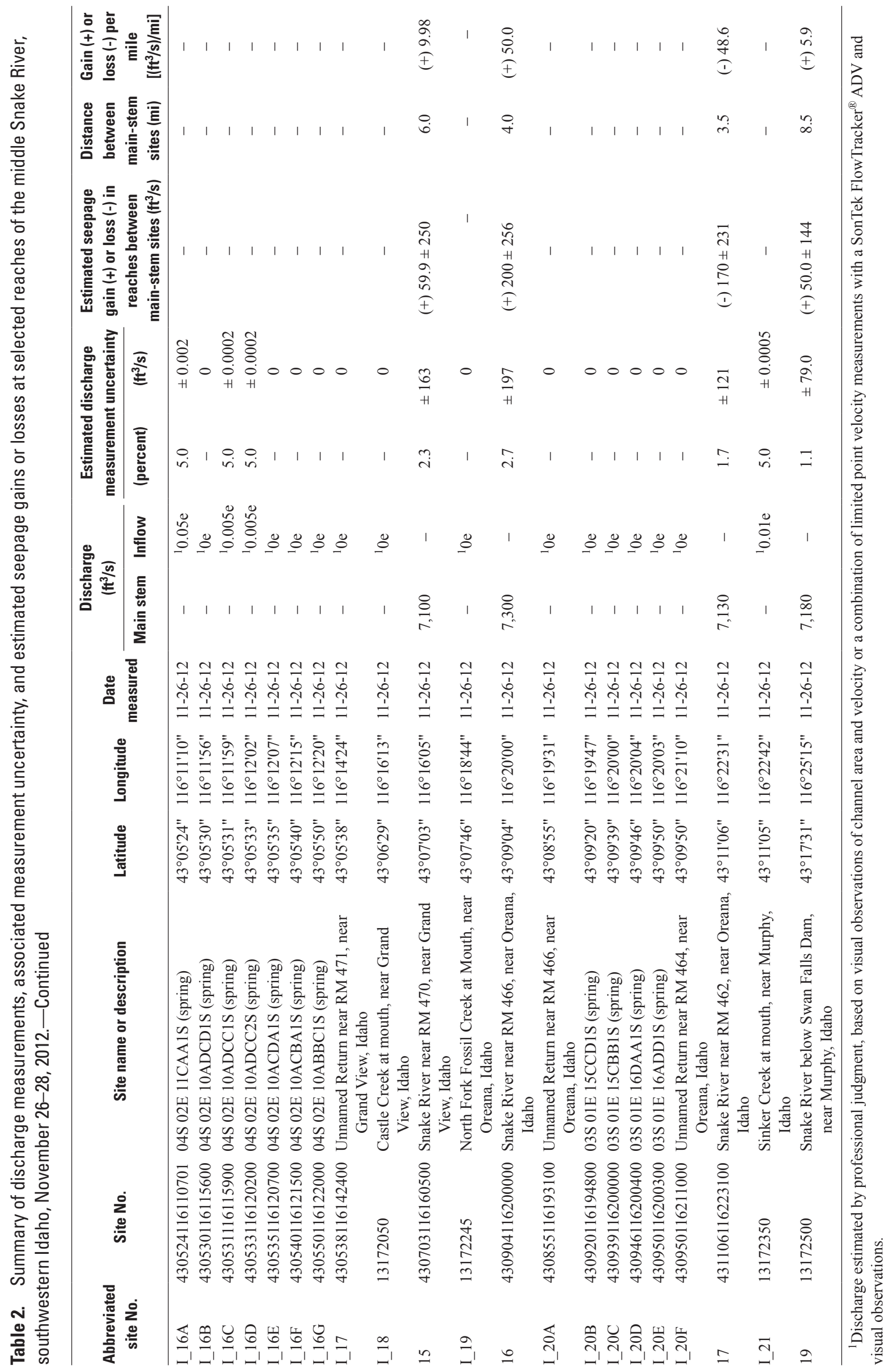




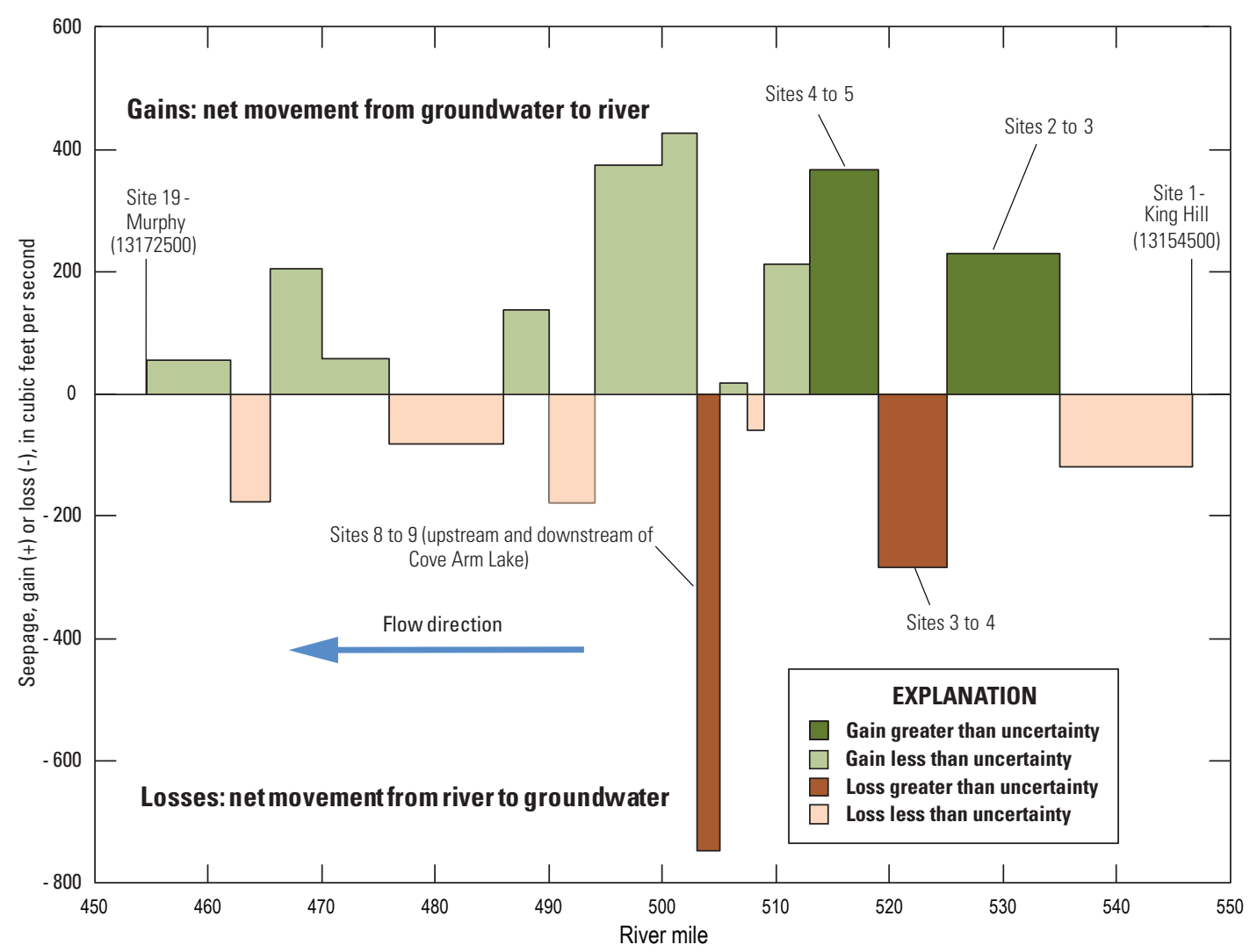

Figure 6. Estimated seepage gains and losses relative to measurement uncertainty for selected reaches of the middle Snake River, southwestern Idaho, November 26-28, 2012.

The reach between main-stem sites 4 and 5 also is immediately downgradient from a large irrigated area just north of the middle Snake River near Mountain Home, Idaho (fig. 1), the drainage from which could be a source of recharge to the river following the irrigation season. Ralston and Chapman (1968) noted the presence of several beds of "beach gravels" on the north side of the middle Snake River near the Idaho State Highway 51 bridge, hereafter referred to as "Loveridge Bridge" (near main-stem site 5; fig. 1), which were described as permeable but not continuous, so they probably do not serve as major aquifers. These beach gravels could be sufficiently continuous on a local scale, however, to explain a net seepage gain in this reach. An unusual net seepage loss was noted upstream and downstream of Cove Arm Lake (fig. 1), between main-stem sites 8 and 9 (fig. 2), but measurements at these sites might have higher uncertainties than those represented in the COV because of low variable velocities $\left(0.4\right.$ and $0.2 \mathrm{ft}^{3} / \mathrm{s}$ average velocities at sites 8 and 9 , respectively) caused by backwater from C J Strike Dam. Water exchange between the middle Snake River and Cove Arm Lake is not well understood and might have a substantial effect on localized seepage estimates in this reach segment. Additional discharge measurements over a range of hydrologic conditions would be useful for confirming seepage estimates upstream and downstream of Cove Arm Lake.

\section{July 2013 Seepage Study}

Net seepage gains and losses between main-stem measurement sites during the July 2013 seepage study all were less than measurement uncertainty (table 3 ). As noted in section, "Methods for Estimating Seepage," discharge measurements made in the reach between main-stem sites 11 and 19 were selected for comparison and calculation of seepage based on travel time estimates in the reach in order to compare the same parcel of water among measurement sites. The sensitivity analysis on this assumption showed that the seepage results would have been similar (seepage less than measurement uncertainty) for any logical combination of measurements in this reach. 


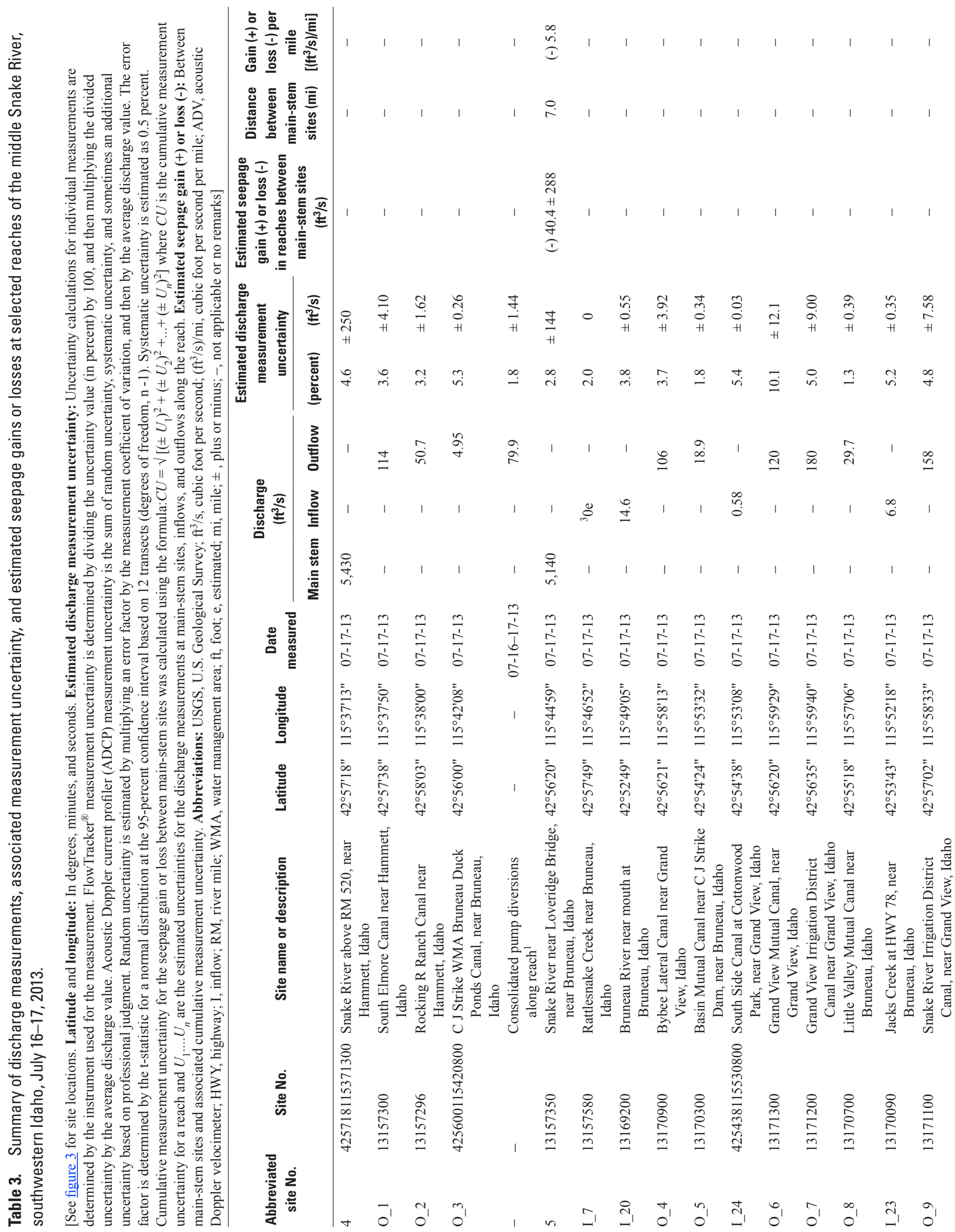




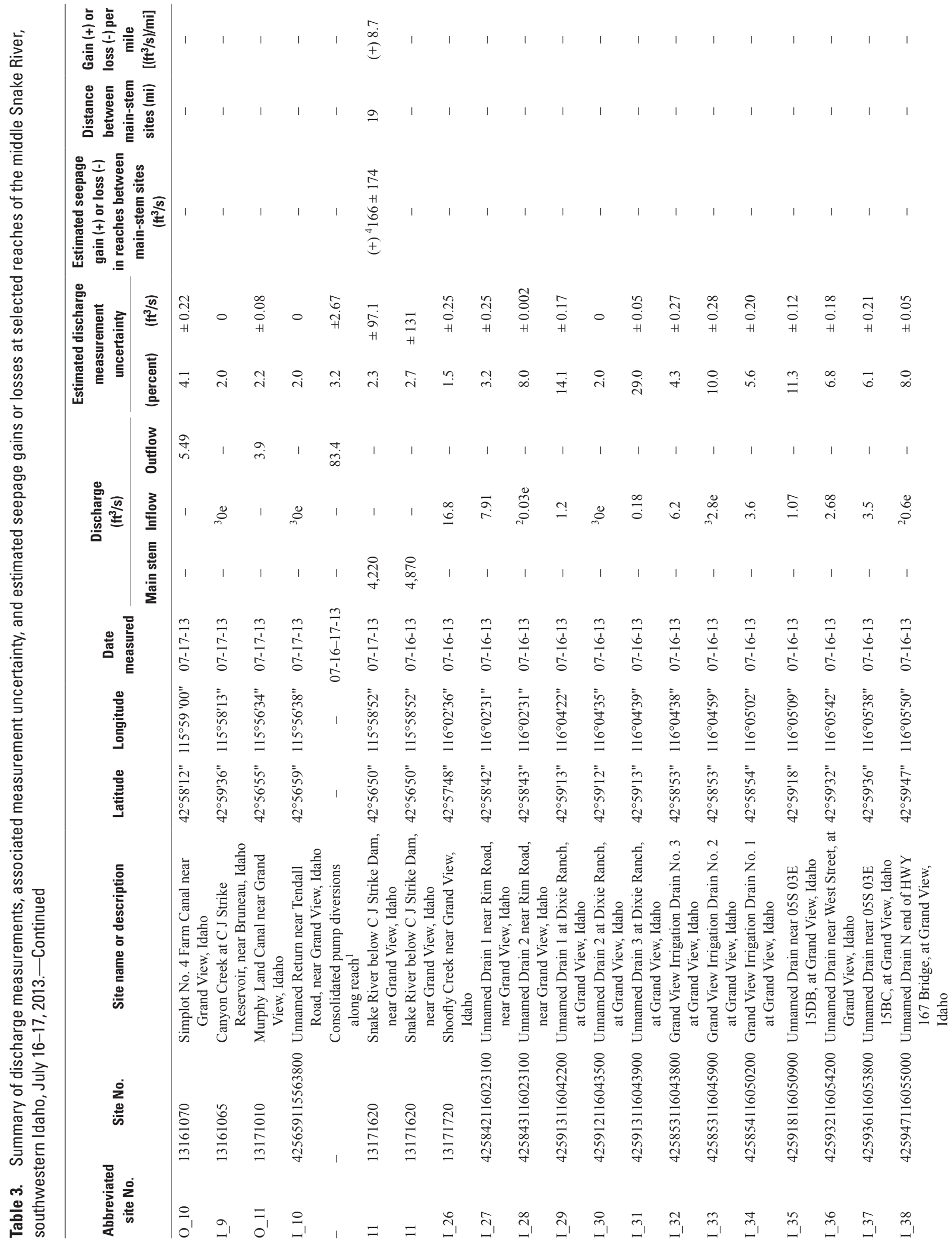




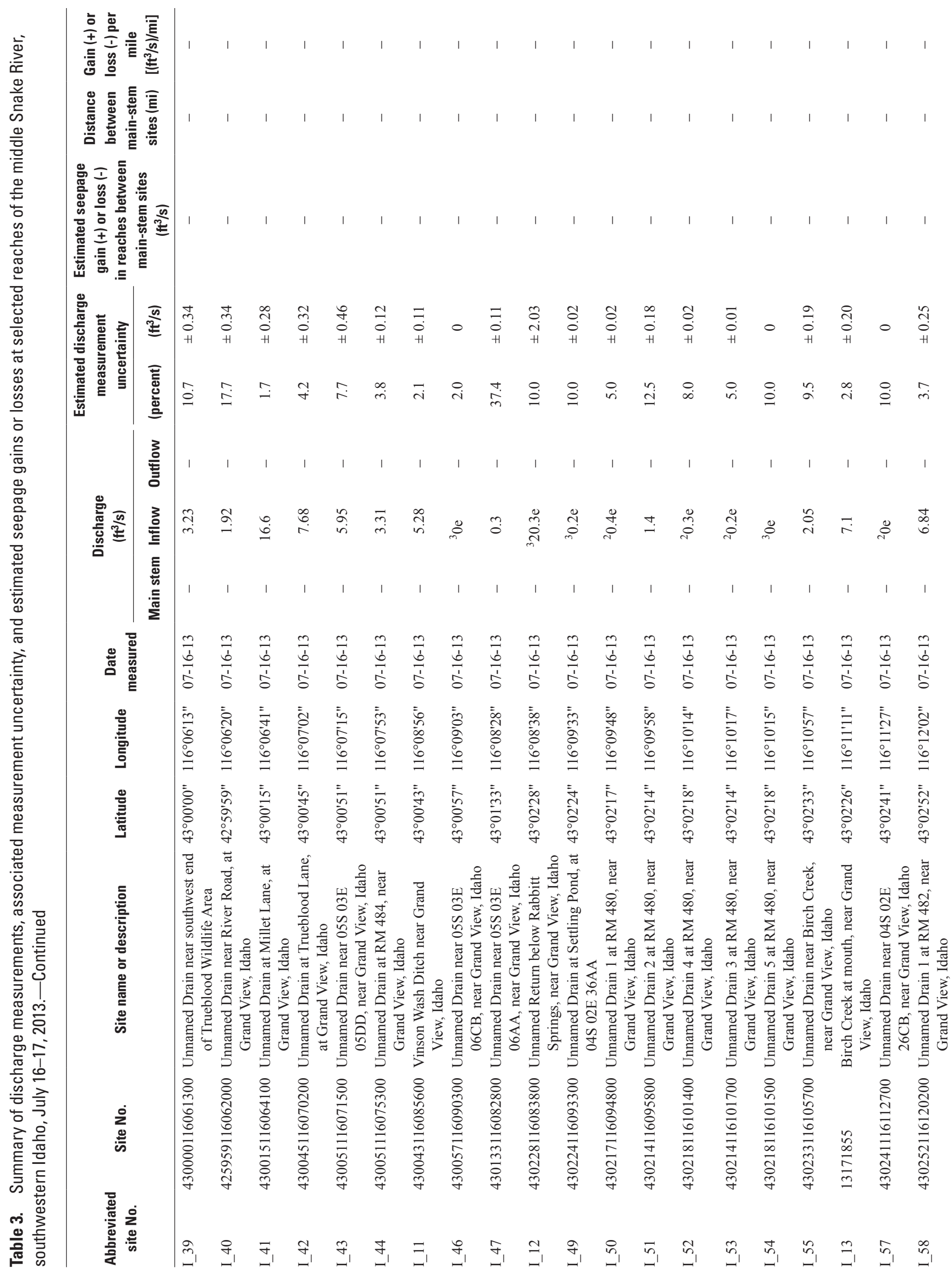




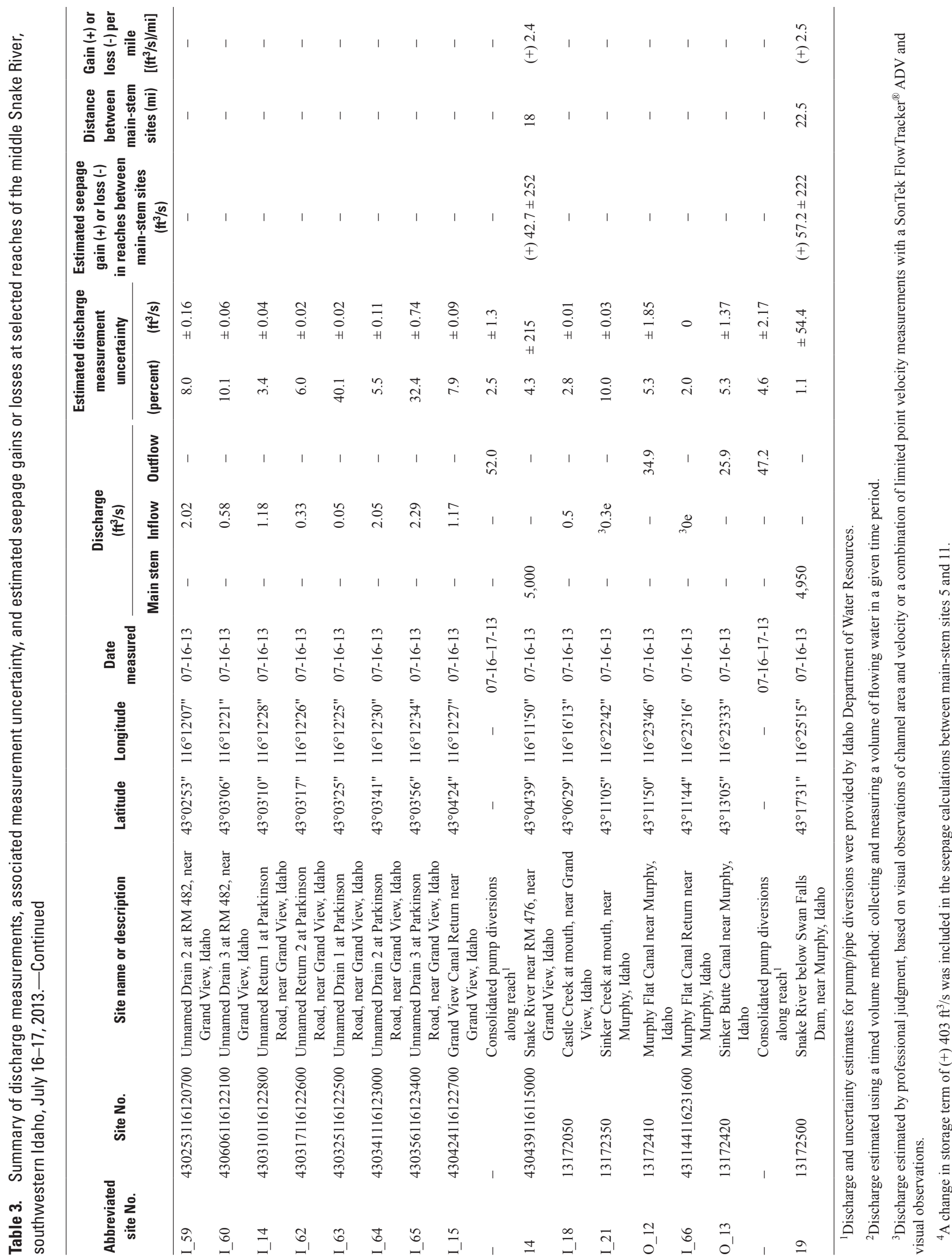




\section{Comparison of Results from November 2012 and July 2013 Seepage Studies}

Examining subreaches measured on the same day during the November 2012 seepage study, and in common with the July 2013 seepage study, the subreaches between main-stem sites 4 and 5, and 5 and 11 both had meaningful seepage gains greater than measurement uncertainty during the November 2012 seepage study, but not during the July 2013 seepage study (table 4). Cumulative uncertainty was slightly higher during the July 2013 seepage study (4-6 percent of measured discharge) than during the November 2012 seepage study (2-3 percent of measured discharge) because more measurements were included in the calculation for each reach. Seepage measured in the subreach between main-stem sites 1 and 4 (fig. 2) was less than measurement uncertainty for the November 2012 seepage study. Similarly, seepage measured in the subreaches between main-stem sites 11 and 19 was less than the measurement uncertainty for both seepage studies, so nothing definitive can be derived about seepage gain or loss conditions in these subreaches. The subreach between main-stem sites 5 and 11 showed a meaningful seepage gain of $217 \mathrm{ft}^{3} / \mathrm{s}$ in the November 2012 seepage study, and a seepage gain in July 2013 seepage study that was slightly less than cumulative measurement uncertainty (table 4). Idaho Power Company recently (2013) installed a streamgage at main-stem site 5 that may serve as the measurement point for inflows to C J Strike Reservoir. If the Flow Method is selected by the SFTWG for calculating Adjusted Average Daily Flow at the Murphy streamgage, the meaningful seepage estimate of $217 \mathrm{ft}^{3} / \mathrm{s}$ between main-stem sites 5 and 11 may need to be included in the routing and adjustment of flow to the Murphy streamgage during nonirrigation season. The total meaningful seepage estimated during the November 2012 study in the reach between mainstem sites 5 and $11\left(217 \mathrm{ft}^{3} / \mathrm{s}\right)$ was about 3.0 percent of the measured discharge at the Murphy streamgage.

Seepage measured in the subreach between main-stem sites 4 and 5 changed substantially between the seepage studies: from a $370 \mathrm{ft}^{3} / \mathrm{s}$ meaningful gain (the largest seepage gain measured among reach segments) in November 2012 to less than the measurement uncertainty in July 2013. Some of the difference in seepage might have resulted from relatively high uncertainty in measurements made at main-stem site 4.

Table 4. Summary of estimated seepage gains and losses for selected subreaches measured in the middle Snake River, southwestern Idaho, November 2012 and July 2013.

[See figures 2 and $\underline{3}$ for locations of subreaches. Seepage estimates in bold typeface are meaningful (greater than measurement uncertainty). Abbreviations: $\mathrm{ft}^{3} / \mathrm{s}$, cubic foot per second; NM, not measured; \pm , plus or minus]

\begin{tabular}{|c|c|c|c|c|c|}
\hline $\begin{array}{l}\text { Subreach } \\
\text { (abbreviated } \\
\text { site No.) }\end{array}$ & Subreach description & $\begin{array}{c}\text { River miles } \\
\text { (approximate) }\end{array}$ & $\begin{array}{c}\text { Dates } \\
\text { measured }\end{array}$ & \multicolumn{2}{|c|}{$\begin{array}{l}\text { Estimated seepage gain }(+) \text { or loss }(-) \\
\text { and associated cumulative measurement } \\
\text { uncertainty }\left(\mathrm{ft}^{3} / \mathrm{s}\right)\end{array}$} \\
\hline 1 to 4 & King Hill to above river mile 520 & $546.6-520$ & November 28, 2012 & $(-) 172 \pm 197$ & NM \\
\hline 5 to 11 & Near Loveridge Bridge to below C J Strike Dam & $513-493.8$ & $\begin{array}{r}\text { November 27, } 2012 \\
\text { and July 17, } 2013\end{array}$ & (+) $217 \pm 175$ & (+) $166 \pm 174$ \\
\hline 11 to 14 & Below C J Strike Dam to near river mile 476 & $493.8-476$ & $\begin{array}{r}\text { November 26, } 2012 \\
\text { and July 16, } 2013\end{array}$ & (-) $123 \pm 226$ & $(+) 42.7 \pm 252$ \\
\hline
\end{tabular}

\footnotetext{
${ }^{1}$ Seepage estimates are presented separately for the reach between sites 1 (King Hill) and 11 (below C J Strike Dam) to remove measurement with relatively high uncertainty at site 4 . The overall seepage estimate was calculated by adding the seepage measured on November 28, 2012, between sites 1 and 5 and on November 27, 2012, between sites 5 and 11, disregarding any additional main-stem measurements between sites. Total corresponding uncertainty was calculated as the square root of the sum of the squared uncertainties for these two subreaches.
} 
Another possible reason for the difference in seepage is that, as noted in the results for the November 2012 seepage study, this reach is downgradient from a heavily irrigated area near Mountain Home, Idaho. Water-level measurements made in monitoring wells drilled in the regional aquifer system on Mountain Home Air Force Base (fig. 1) in 2012 and 2013 indicate a seasonal decline in the groundwater table among measurements made in December 2012, June 2013, and September 2013 (Williams, 2014), which is similar to patterns in seepage measured for the subreaches between main-stem sites 4 and 5, and 5 and 11 (fig. 7). The estimated 5-ft seasonal decline in the regional water table between December 2012 and September 2013 (fig. 7) and water consumption (crop uptake and evapotranspiration) in the irrigated areas might have caused the measured change in seepage patterns in this reach between the two seepage studies. Williams (2014) measured an average $1.08 \mathrm{ft} / \mathrm{yr}$ decline in the regional water table in monitoring wells on the Mountain Home Air Force Base (fig. 1) from the early 2000s to 2013. If this rate of decline in water levels is present across the entire study reach, water-table elevations presented in Lindholm and others (1988) would now be lower than the elevation of the streambed between main-stem sites 11 and 19, which could explain why measured seepage was not meaningful in these subreaches in both November 2012 and July 2013 seepage studies.

Discharge measurements at main-stem site 4 had a higher uncertainty than discharge measurements made at other main-stem sites measured on the same day (tables 2 and $\underline{3}$ ) because of less-than-ideal measurement conditions at site 4 . As a result, discharge measurements made on the same day during the November 2012 seepage study at main-stem sites 1 and 11 and on any intervening inflows also were used to calculate an overall estimate of seepage in the subreach between King Hill and C J Strike Dam (table 4), to compare results with those generated using a groundwater-flow model and published by Newton (1991). This method disregards the results of any main stem discharge measurements made in subreaches between main-stem sites 1 and 11 . The results showed a meaningful net seepage gain of $415 \mathrm{ft}^{3} / \mathrm{s}$ between main-stem sites 1 and 11 in November 2012, which is similar to the net seepage gain estimated by Newton (1991) for the overall reach from King Hill to Murphy $\left(461 \mathrm{ft}^{3} / \mathrm{s}\right)$ using a groundwater model. The total meaningful seepage estimated during the November 2012 study in the subreach from main-stem sites 1 and $11\left(415 \mathrm{ft}^{3} / \mathrm{s}\right)$ was about 5.8 percent of the measured discharge at the Murphy streamgage. Seepage for the subreach between main-stem sites 1 and 11 could not be calculated for the July 2013 seepage study because no discharge measurements were made on inflows and outflows upstream of main-stem site 4. Most of the meaningful seepage measured during the November 2012 seepage study likely is owing to groundwater discharging directly into the river channel or from unseen seeps immediately adjacent to the river because seeps and springs measured or observed during the November 2012 seepage study accounted for less than $1 \mathrm{ft}^{3} / \mathrm{s}$.

Although seepage conditions in the main stem channel can vary throughout seasons and among years because of changes in hydrology and climate, the calculated, meaningful seepage estimates are considered representative of typical seepage conditions expected during the non-irrigation season near the minimum Adjusted Average Daily Flow thresholds. Seepage calculated between main-stem sites in the July 2013 seepage study was less than measurement uncertainty, so nothing definitive can be derived about seepage gain or loss conditions in these subreaches during irrigation season. Seepage rates might change and become meaningful, particularly during the irrigation season, if water levels rebound in the study area. Continued water level monitoring in wells may be useful for tracking the potential for a change in groundwater-surface water interactions and for determining whether additional seepage studies may be needed in the future.

\section{Quality-Assurance Measurements}

Comparison discharge measurements made for quality assurance averaged within 0.8 percent of the primary discharge measurements made during the November 2012 seepage study and within 2.0 percent of primary discharge measurements made during the July 2013 seepage study (table 5). The larger percentage differences between comparison and primary discharge measurements made during the July 2013 seepage study likely are owing to greater variability in velocities and instrument limitations at the lower discharges measured in July 2013 compared to discharges measured in November 2012. During the controlled comparison discharge measurement experiments made by USGS and Idaho Power Company personnel on October 31, 2012, and July 10, 2013, in the New York Canal (not presented on table 5), comparison discharge measurements made using ADCPs that were used in the seepage computation were within plus or minus 2.3 percent of the average primary discharge. Based on results of all comparison measurements made as part of the seepage studies, no appreciable bias appears to be present with any particular instrument used. 


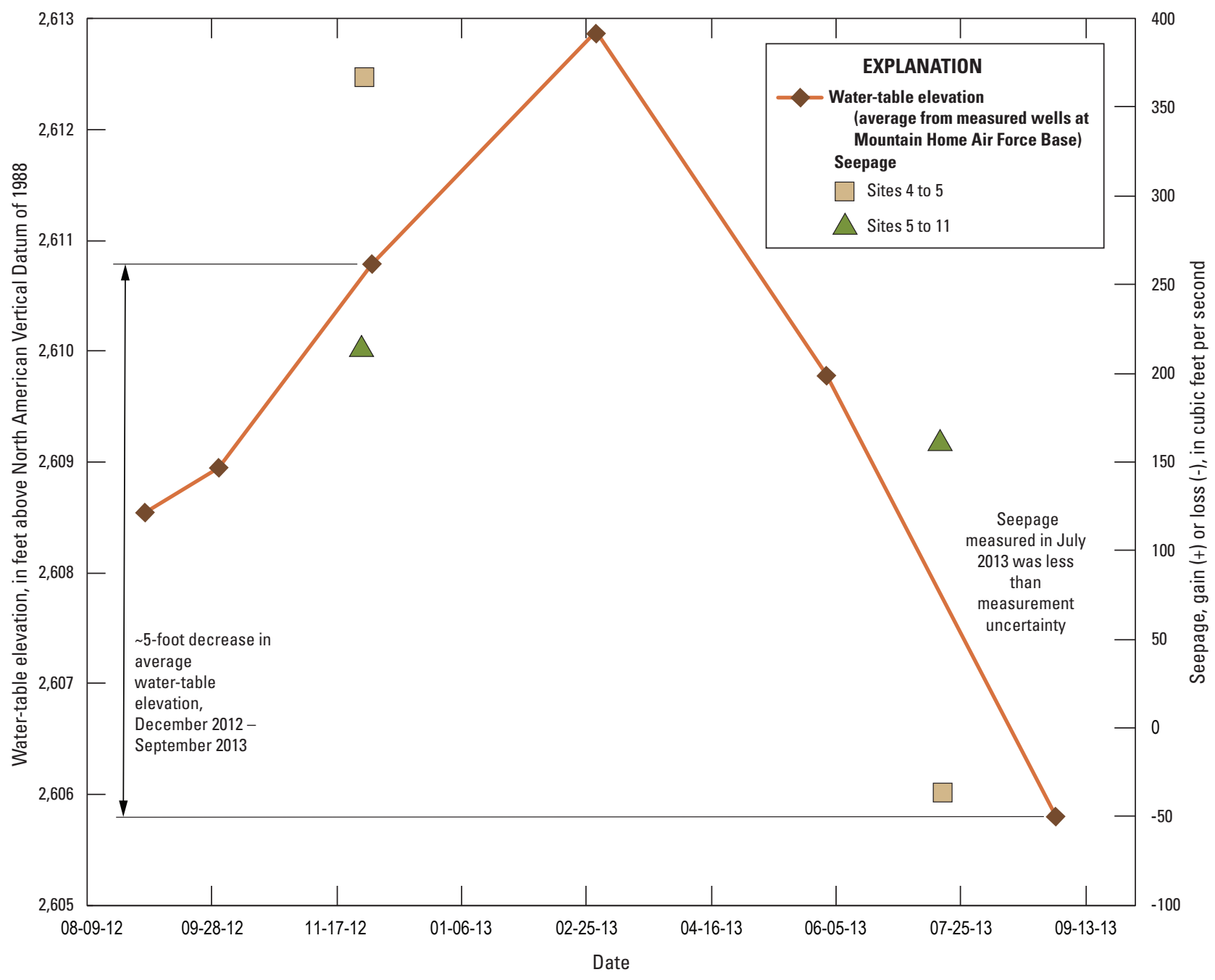

Figure 7. Average water-table elevations measured in wells on the Mountain Home Air Force Base,

September 2012-13, and seepage estimates in selected reaches between main-stem sites 4 and 5 , and 5 and 11, middle Snake River, southwestern Idaho, November 2012 and July 2013. 
Table 5. Comparison discharge measurements made for quality assurance during seepage studies in the middle Snake River, southwestern Idaho, November 2012 and July 2013.

[See figures 2 and $\underline{3}$ for site locations. Unless otherwise noted, primary discharge measurements were made with a Teledyne RD Instruments Rio Grande 1200-kHz ADCP and comparison discharge measurements were made with a SonTek RiverSurveyor ${ }^{\mathbb{B}}$ M9 multi-frequency ADCP. Abbreviations: $\mathrm{ft}^{3} / \mathrm{s}$, cubic foot per second; kHz, kiloHertz; ADCP, acoustic Doppler current profiler; RM, river mile; USGS, U.S. Geological Survey]

\begin{tabular}{|c|c|c|c|c|c|c|}
\hline $\begin{array}{l}\text { Abbreviated } \\
\text { site No. }\end{array}$ & Site No. & Site name or description & $\begin{array}{l}\text { Measurement } \\
\quad \text { date }\end{array}$ & $\begin{array}{c}\text { Primary } \\
\text { discharge } \\
\left(\mathrm{ft}^{3} / \mathrm{s}\right)\end{array}$ & $\begin{array}{c}\text { Comparison } \\
\text { discharge } \\
\left(\mathrm{ft}^{3} / \mathrm{s}\right)\end{array}$ & $\begin{array}{c}\text { Difference } \\
\text { between primary } \\
\text { and comparison } \\
\text { discharge } \\
\text { (percent) }\end{array}$ \\
\hline \multicolumn{7}{|c|}{ November 2012 seepage study } \\
\hline 1 & 13154500 & Snake River at King Hill, Idaho & $11-28-12$ & 6,910 & 6,903 & -0.1 \\
\hline 4 & 425718115371300 & $\begin{array}{l}\text { Snake River above RM 520, near Hammett, } \\
\text { Idaho }\end{array}$ & $11-28-12$ & 6,749 & 6,776 & 0.4 \\
\hline 5 & 13157350 & $\begin{array}{l}\text { Snake River near Loveridge Bridge, near } \\
\text { Bruneau, Idaho }\end{array}$ & $11-28-12$ & 7,116 & 7,330 & 3.0 \\
\hline 5 & 13157350 & $\begin{array}{l}\text { Snake River near Loveridge Bridge, near } \\
\text { Bruneau, Idaho }\end{array}$ & $11-27-12$ & 6,859 & 7,095 & 3.4 \\
\hline 10 & 425919115545500 & Snake River near RM 501, near Bruneau, Idaho & $11-27-12$ & 6,708 & 6,617 & -1.4 \\
\hline 11 & 13171620 & $\begin{array}{l}\text { Snake River below C J Strike Dam, near Grand } \\
\text { View, Idaho }\end{array}$ & $11-26-12$ & 7,164 & 7,060 & -1.5 \\
\hline 11 & 13171620 & $\begin{array}{l}\text { Snake River below C J Strike Dam, near Grand } \\
\text { View, Idaho }\end{array}$ & $11-27-12$ & 7,157 & 7,314 & 2.2 \\
\hline \multirow[t]{2}{*}{19} & 13172500 & $\begin{array}{l}\text { Snake River below Swan Falls Dam, near } \\
\text { Murphy, Idaho }\end{array}$ & $11-26-12$ & 7,181 & 7,182 & 0.0 \\
\hline & & & & & Average & 0.8 \\
\hline \multicolumn{7}{|c|}{ July 2013 seepage study } \\
\hline 4 & 425718115371300 & $\begin{array}{l}\text { Snake River above RM 520, near Hammett, } \\
\text { Idaho }\end{array}$ & $7-17-13$ & 5,470 & 5,470 & 0.0 \\
\hline 5 & 13157350 & $\begin{array}{l}\text { Snake River near Loveridge Bridge, near } \\
\text { Bruneau, Idaho }\end{array}$ & $7-17-13$ & 5,150 & 5,430 & 5.3 \\
\hline 11 & 13171620 & $\begin{array}{l}\text { Snake River below C J Strike Dam, near Grand } \\
\text { View, Idaho }\end{array}$ & $7-17-13$ & 4,210 & 4,260 & 1.2 \\
\hline 14 & 430439116115000 & $\begin{array}{l}\text { Snake River near RM 476, near Grand View, } \\
\text { Idaho }\end{array}$ & $7-16-13$ & 4,920 & 5,260 & 6.7 \\
\hline 19 & 13172500 & $\begin{array}{l}\text { Snake River below Swan Falls Dam, near } \\
\text { Murphy, Idaho }\end{array}$ & $7-16-13$ & 4,890 & 4,740 & -3.1 \\
\hline O_4 & 13170900 & Bybee Lateral Canal, near Grand View, Idaho & $7-17-13$ & ${ }^{1} 106$ & ${ }^{1} 109$ & 2.8 \\
\hline O_6 & 13171300 & $\begin{array}{l}\text { Grand View Mutual Canal near Grand View, } \\
\text { Idaho }\end{array}$ & $7-17-13$ & ${ }^{1} 120$ & ${ }^{1} 122$ & 1.7 \\
\hline \multirow[t]{2}{*}{ O_7 } & 13171200 & $\begin{array}{l}\text { Grand View Irrigation District Canal, near } \\
\text { Grand View, Idaho }\end{array}$ & $7-17-13$ & ${ }^{1} 180$ & ${ }^{1} 183$ & 1.7 \\
\hline & & & & & Average & 2.0 \\
\hline
\end{tabular}

${ }^{1}$ Discharge measurement made with a Teledyne RD Instruments StreamPro 2000kHz ADCP. 


\section{Discharge Uncertainty Evaluation}

Seepage estimates are needed for the calculation of Adjusted Average Daily Flow at the Murphy streamgage (13172500) if the Flow Method is selected by the SFTWG; however, the uncertainty in average daily discharge records used in the calculation of Adjusted Average Daily Flow also must be considered regardless of method used, particularly when flows are near the Adjusted Average Daily Flow thresholds. Estimating discharge measurement uncertainty when flows are near the Adjusted Average Daily Flow thresholds informs water resource managers about the precision of the flow data. The USGS evaluated and quantified uncertainty in instantaneous discharge measurements and in computed discharge in water years (WYs) 2007-11 at four streamgages operated by Idaho Power Company in the study reach (table 1). A water year is the 12-month period from October 1 for any given year through September 30 of the following year. The water year is designated by the calendar year in which it ends.

\section{Description of Streamgages}

\section{Snake River below Lower Salmon Falls Dam, near Hagerman, Idaho (Site 13135000)}

Idaho Power Company streamgage 13135000 (hereafter referred to as the "Lower Salmon Falls streamgage") is on the middle Snake River about $0.5 \mathrm{mi}$ downstream of the Lower Salmon Falls Dam and about 1 mi upstream of the Malad River confluence with the Snake River (fig. 1, table 1). Discharge is computed using a relation between stage and discharge, called a "rating". The streamgage is on a fairly straight reach of the middle Snake River where the channel is about $340 \mathrm{ft}$ wide. The channel feature that controls the stage-discharge rating (hereafter referred to as the "control") at low discharge is a rock riffle about $1,000 \mathrm{ft}$ downstream of the streamgage and 3,500 $\mathrm{ft}$ downstream of the Lower Salmon Falls Dam. The control appears stable and well defined.

\section{Snake River below Bliss Dam, near Bliss, Idaho (Site 13153776)}

Idaho Power Company streamgage 13153776 (hereafter referred to as the "Bliss streamgage") is on the middle Snake River about 1 mi downstream of Bliss Dam (fig. 1, table 1). Discharge is computed using a stage-discharge rating. The streamgage is on a fairly straight reach of the Snake River where the channel is about $150 \mathrm{ft}$ wide. The control is a bedrock outcrop at the upstream end of a riffle about $0.1 \mathrm{mi}$ downstream of the streamgage.

\section{Snake River below C J Strike Dam, near Grand View, Idaho (Site 13171620)}

Idaho Power Company streamgage 13171620 (hereafter referred to as the "C J Strike streamgage") is about $0.3 \mathrm{mi}$ downstream of C J Strike Dam on the middle Snake River (fig. 1, table 1). Two distinct channels, one leading from the dam spillway and the other leading from the powerhouse, converge just upstream of the streamgage. The streamgage structure is mounted on the downstream side of a bridge downstream of the confluence of the two channels. The spillway channel from C J Strike Dam is active only during periods of spill, typically at higher discharges. Unlike other streamgages evaluated in this study, discharge at the streamgage is computed using the index-velocity method described in Levesque and Oberg (2012). A 600-kHz horizontal acoustic Doppler current profiler (H-ADCP) is used to measure velocity in a fixed part of the channel on the upstream side of the bridge, which is then related to the overall average channel velocity in an index-velocity rating. A standard cross section, $50 \mathrm{ft}$ upstream of the streamgage, is surveyed periodically to develop a rating between stage and cross-sectional area. Average channel velocity from the index-velocity rating is multiplied by the area from the stage-area rating to calculate a continuous record of discharge. Idaho Power Company sometimes estimates discharge at the streamgage using a traditional stage-discharge rating if the H-ADCP malfunctions or produces erroneous data. Discharge measurements at index-velocity streamgages are more dependent on channel conditions near the velocity meter and standard cross section, and are less dependent on conditions at a downstream control, as would be the case for a stage-discharge streamgage. Channel scour, infilling by sediment, and aquatic vegetation growth at or in the immediate vicinity of the cross section measured by the velocity meter can potentially cause changes in the velocity profile and the index-velocity rating.

\section{Snake River below Swan Falls Dam, near Murphy, Idaho (Site 13172500)}

Idaho Power Company streamgage 13172500 (referred to as the "Murphy streamgage") is about 4.2 mi downstream of the Swan Falls Dam and 7 mi northeast of Murphy, Idaho (fig. 1, table 1). The streamgage serves as the measurement point for distribution of water to the hydropower and minimum flow water rights as assigned in the partial decrees. Discharge is computed using a stage-discharge rating. Based on physical inspection by USGS during July 2012 at a discharge of about $8,000 \mathrm{ft}^{3} / \mathrm{s}$, the control appears to be a channel contraction and rock riffle 1,000 ft downstream of the streamgage. The right side of the channel at the control 
is a bedrock outcrop and is resistant to scour and infilling by sediment. The left bank is gently sloped and consists of sand and gravel intermixed with medium-sized boulders, and is affected by scour and infilling by sediment during highdischarge conditions. The entire channel near the control is affected by heavy aquatic vegetation growth during lowto-mid discharge conditions, which requires large, frequent changes or shifts in the stage-discharge rating. Shifts to stage applied by Idaho Power Company during periods of heavy aquatic vegetation growth were as large as $-0.90 \mathrm{ft}$ in WYs 2007-11. In comparison, the largest shift applied because of aquatic vegetation growth or sediment infill at the other three streamgages operated by Idaho Power Company in the study reach in WYs $2007-11$ was $-0.15 \mathrm{ft}$ at the Lower Salmon Falls streamgage (13135000).

\section{Methods for Estimating Discharge Uncertainty}

The USGS reviewed stage and velocity (where applicable) measurements, discharge measurements, computed discharge records, and other available data from WYs 2007-11 for the four Idaho Power Company streamgages along the study reach (fig. 1, table 1). The USGS also evaluated discharge rating and shifting techniques and assessed uncertainty for average daily discharge computations produced by Idaho Power Company and published by the USGS. Although the measurement point for the hydropower and minimum flow water rights is the Murphy streamgage, uncertainty in discharge was evaluated for all four streamgages because changes in reservoir storage (converted to discharges) will be routed through the study reach and used in the calculation of Adjusted Average Daily Flow at the Murphy streamgage.

\section{Discharge Measurements}

The USGS reviewed ADCP measurements made in WYs 2007-11 at four streamgages and estimated uncertainty for each measurement, according to the methods described for the seepage studies in the section, "Discharge Measurement Uncertainty." The number of transects per measurement and the corresponding t-statistic varied among measurements. Average uncertainty was calculated for all measurements with discharge equal to or less than the Adjusted Average Daily Flow thresholds 3,900 and 5,600 ft $3 / \mathrm{s}$, and at two arbitrary "warning levels" for low discharge selected by the USGS, 6,000 and $7,000 \mathrm{ft}^{3} / \mathrm{s}$.

\section{Discharge Ratings}

The USGS calculated 95-percent prediction intervals for instantaneous and average daily discharge by analyzing parts of the discharge rating at each site at low discharge (less than $9,000-10,000 \mathrm{ft}^{3} / \mathrm{s}$, depending on the site). The prediction intervals could not be calculated for discharges greater than this level because at most of the streamgages, the rating is not linear throughout the range of discharges, and separate 95-percent prediction intervals would have to be developed for each linearized segment of the rating. Prediction intervals and uncertainty were assessed at the 3,900 and 5,600 $\mathrm{ft}^{3} / \mathrm{s}$ Adjusted Average Daily Flow thresholds and at the 6,000 and $7,000 \mathrm{ft}^{3} / \mathrm{s}$ warning levels.

To calculate the 95-percent prediction intervals, a linear part of the rating line was selected, and a regression line was fit through measurements used to create the rating line in this part of the overall rating. Regression lines were created to match the rating lines in use for the Lower Salmon Falls (rating 9.1) and Murphy (rating 9.1) streamgages because they originally had been drawn by hand. Prediction intervals for the C J Strike streamgage could be calculated directly because the rating in use (rating 3) was generated using linear regression (fig. 8). Prediction intervals could not be calculated for the Bliss streamgage because of the high degree of curvature in the rating (rating 7.1) at low discharge. For the Lower Salmon Falls, C J Strike, and Murphy streamgages, prediction intervals were calculated based on the standard error of the regression line and other variables according to equation 5 from Lapin (1997), which was developed for small sample sizes:

$$
Y_{1}(X)=\hat{Y}(X) \pm t \frac{\alpha}{2} s_{Y, X} \sqrt{\frac{1}{n}+\frac{(X-\bar{X})^{2}}{\sum X^{2}-\left(\frac{1}{n}\right)\left(\sum X\right)^{2}}}+1
$$

where

$Y_{1}(X)$ is the upper or lower bound of the predicted variable given a value of $X$, corresponding to discharge or average channel velocity depending on the site;

$\hat{Y}(X)$ is the average predicted variable given a value of $X$; $t \frac{\alpha}{2}$ is the two-tailed t-statistic at a confidence
level $\alpha$ and degrees of freedom equal to $n-2$;

$s_{Y, X}$ is the standard error of the regression between $X$ and $Y$;

$n$ is the number of observations in the regression between $X$ and $Y$;

$X$ is a given value of the explanatory variable, which is stage or velocity depending on site;

$\bar{X}$ is the average value of explanatory variables used in the regression between $X$ and $Y$;

$\sum X^{2}$ is the sum of squared values of explanatory variables used in the regression between $X$ and $Y$; and

$\left(\sum X\right)^{2}$ is the square of the sum of values of explanatory variables used in the regression between $X$ and $Y$. 


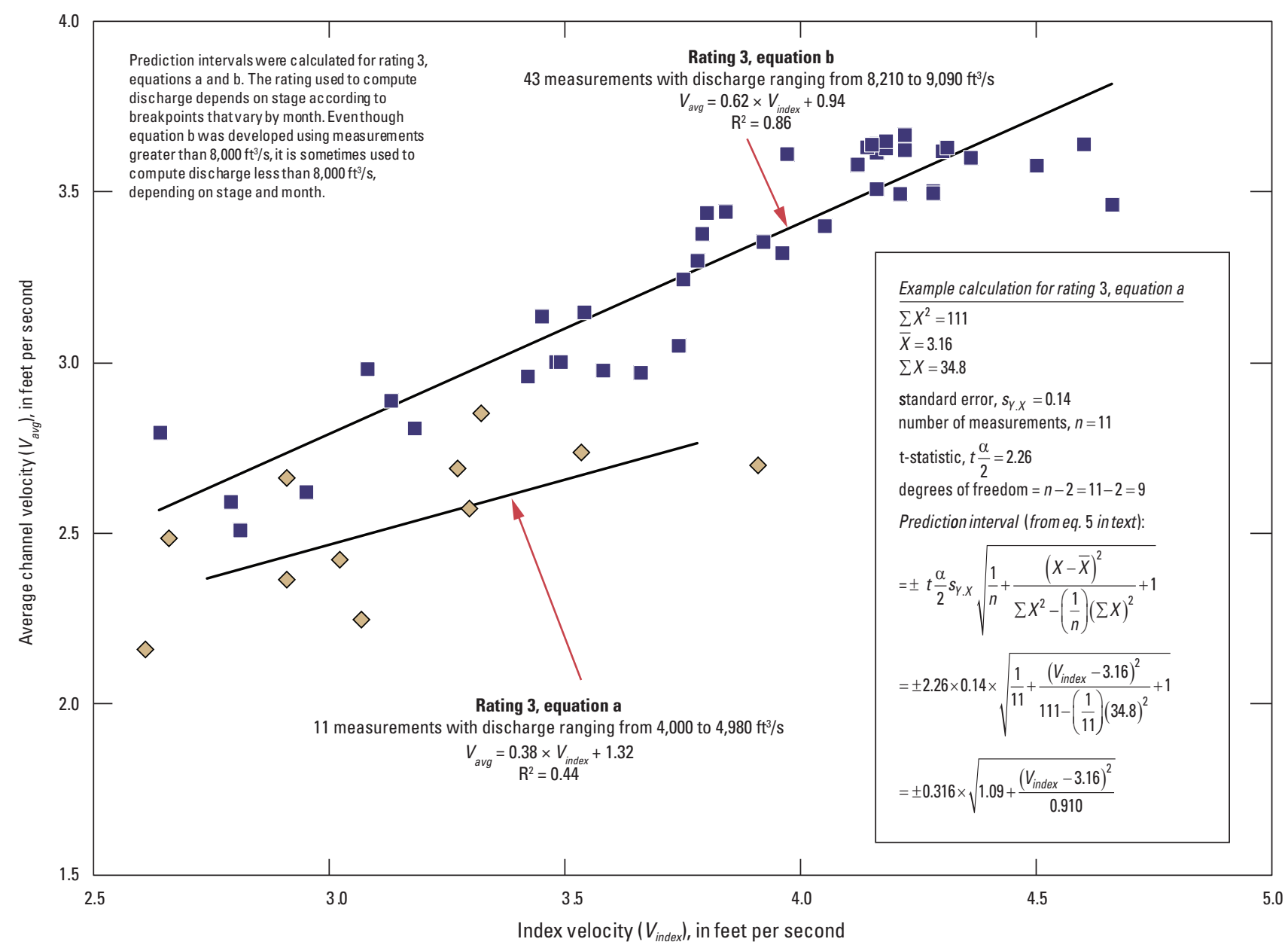

Figure 8. Index-velocity ratings used to calculate prediction intervals at Adjusted Average Daily Flow thresholds and selected warning levels for the Snake River below C J Strike Dam, near Grand View, Idaho (site 13171620).

Uncertainty in discharge computed from ratings was calculated using the 95-percent prediction intervals in one of two ways:

1. Murphy and Lower Salmon Falls streamgages.

Prediction intervals were calculated using the stage corresponding to the discharge at each of the thresholds or warning levels $\left(3,900,5,600,6,000\right.$, and $\left.7,000 \mathrm{ft}^{3} / \mathrm{s}\right)$ based on the stage-discharge rating. The prediction interval then was converted to a percent error relative to the discharge value at the threshold or warning level. For example, if the prediction interval for a streamgage is plus or minus $320 \mathrm{ft}^{3} / \mathrm{s}$ at the $6,000 \mathrm{ft}^{3} / \mathrm{s}$ warning level, the corresponding percent error at that warning level is plus or minus $320 \mathrm{ft}^{3} / \mathrm{s}$ divided by $6,000 \mathrm{ft}^{3} / \mathrm{s}$, or plus or minus 5.3 percent.

2. C J Strike streamgage. Prediction intervals could not be calculated directly at thresholds or warning levels using method 1 at the $\mathrm{C} J$ Strike streamgage because a two-parameter index-velocity rating (rating 3 ) is used to calculate discharge, and multiple combinations of stage and velocity measurements could result in the discharge at a particular threshold or warning level. Additionally, the index-velocity rating has three sub-ratings or equations. Low and high breakpoints in stage, which vary by month, determine which of the three equations are used. The prediction interval analysis focused on equations $\mathrm{a}$ and $\mathrm{b}$ in figure 8 , which include low discharges of as much as about $9,000 \mathrm{ft}^{3} / \mathrm{s}$ (fig. 8). Equation b in figure 8 was developed using discharge measurements greater than $8,000 \mathrm{ft}^{3} / \mathrm{s}$ but is sometimes used to compute discharges of less than $8,000 \mathrm{ft}^{3} / \mathrm{s}$, depending on stage and month. Unlike in method 1 used for the Murphy and Lower Salmon Falls streamgages, prediction intervals for the C J Strike streamgage were calculated for each instantaneous (15-minute) computed discharge based on actual instantaneous stage and velocity measurements in WY 2011, selected because rating 3 was developed and implemented that year, to quantify uncertainty of computed discharges of less than $9,000 \mathrm{ft}^{3} / \mathrm{s}$. 
The instantaneous upper and lower prediction intervals were averaged for each day and converted to a percent error relative to the computed average daily discharge. Overall average percent errors then were calculated for discharges less than the selected discharge thresholds or warning levels based on WY 2011 data.

The prediction intervals and associated uncertainty in computed discharge incorporate uncertainty in stage and velocity readings and discharge measurements, particularly random uncertainty. Some types of measurement bias, if consistent, might not be well represented by the prediction intervals. However, at all sites, measurements were made using various types of ADCPs and different ADCP and boat operators, so the likelihood of a consistent, undetected bias is low.

\section{Discharge Uncertainty Estimates}

Equipment and techniques used by Idaho Power Company to measure stage, velocity, and discharge at the four evaluated streamgages met USGS requirements in Rantz (1982), Mueller and Wagner (2009), Sauer and Turnipseed (2010), Turnipseed and Sauer (2010), Levesque and Oberg (2012), and various USGS policy memorandums. Discharge uncertainty is quantified using 95 -percent prediction intervals, which means that there is 95-percent confidence that the true average daily discharge is within the stated percentage of the computed average daily discharge at a given threshold or warning level. For this report, the prediction intervals for computed average daily discharge represent the total quantifiable uncertainty near the identified thresholds and warning levels.

\section{Snake River below Lower Salmon Falls Dam, near Hagerman, Idaho (Site 13135000)}

Prediction intervals for the Lower Salmon Falls streamgage were determined for the part of stage-discharge rating 9.1 with discharges less than $9,000 \mathrm{ft}^{3} / \mathrm{s}$ (table 6). About one-half of the uncertainty in the computed discharge represented by the prediction interval consists of measurement uncertainty (4.3-4.5 out of 8.4-9.3 percent; table 6). Uncertainty in discharge increases as discharge decreases, primarily because of the limited number of measurements that have been made at discharges less than 5,600 ft $3 / \mathrm{s}$. Discharge measurement uncertainty at the $3,900 \mathrm{ft}^{3} / \mathrm{s}$ threshold could not be assessed because the lowest discharge measured in WYs $2007-11$ was $4,030 \mathrm{ft}^{3} / \mathrm{s}$; however, the prediction interval could be calculated because the rating extends below the lowest measured discharge. Discharges near the $3,900 \mathrm{ft}^{3} / \mathrm{s}$ threshold are rare, so uncertainty in computed discharge might be even higher than is represented by the prediction interval at this threshold because of a lack of measurements available to define the stage-discharge rating.

\section{Snake River below Bliss Dam, near Bliss, Idaho (Site 13153776)}

Prediction intervals could not be calculated for the Bliss streamgage because of the high degree of curvature in rating 7.1 at low discharge. Discharge record uncertainty can be no less than the average uncertainty of the discharge measurements, which was 6.3 percent at discharges less than $7,000 \mathrm{ft}^{3} / \mathrm{s}$ (table 6). Average measurement uncertainty at discharges less than $6,000 \mathrm{ft}^{3} / \mathrm{s}$ was 6.0 percent; however, only one measurement was available for the calculation (table 6). Determination of uncertainty at low discharges, when they occur, would be improved with more measurements near the thresholds of interest. The site selected for discharge measurements is poor because of low, highly variable velocities near the operating limit of ADCPs used to measure discharge. Idaho Power Company and the USGS have discussed alternative measurement sites and acknowledge that a more suitable measuring site might not be present near the streamgage, but agree that additional field reconnaissance is needed.

\section{Snake River below C J Strike Dam, near Grand View, Idaho (Site 13171620)}

At the C J Strike streamgage, about 60-80 percent of the uncertainty represented by the prediction interval consists of measurement uncertainty at the selected thresholds and warning levels (7.8 out of 9.5-13.6 percent; table 6). Discharge measurement uncertainty at the $3,900 \mathrm{ft}^{3} / \mathrm{s}$ threshold could not be assessed because the lowest discharge measured in WYs $2007-11$ was $4,350 \mathrm{ft}^{3} / \mathrm{s}$. Uncertainty also could not be assessed in computed discharge at the $3,900 \mathrm{ft}^{3} / \mathrm{s}$ threshold because the lowest average daily discharge in WY 2011 was $5,800 \mathrm{ft}^{3} / \mathrm{s}$. Uncertainty at the $5,600 \mathrm{ft}^{3} / \mathrm{s}$ threshold was determined using the average percent errors from the instantaneous discharges, which were less than $5,600 \mathrm{ft}^{3} / \mathrm{s}$ threshold on several days. Overall, uncertainty at this streamgage is high relative to the other streamgages in this analysis because of a poor measurement site at low discharges (upstream of an island that causes non-uniform velocities), limitations of the H-ADCP at low velocities, and the number of ratings in use (three index-velocity sub-ratings and a stage-area rating). Uncertainty in computed discharge owing to uncertainty in the stage-area rating was not quantified for this analysis, but is not expected to be a source of substantial error because techniques used to survey the standard cross section follow USGS policies in Levesque and Oberg (2012). Additionally, the streambed at the standard cross section is bedrock and is not altered by scour and infilling by sediment. 
Table 6. Uncertainty estimates for discharge measurements and computed discharge at Adjusted Average Daily Flow thresholds and selected warning levels for four streamgages operated by Idaho Power Company, middle Snake River, southwestern Idaho, water years 2007-11.

[See figure 1 for site locations. Abbreviations: $\mathrm{ft}^{3} / \mathrm{s}$, cubic foot per second, NA, not applicable/could not calculate; \pm , plus or minus]

\begin{tabular}{|c|c|c|c|c|}
\hline \multirow[b]{2}{*}{$\begin{array}{l}\text { Adjusted Average } \\
\text { Daily Flow threshold or } \\
\text { warning level } \\
\left(\mathrm{ft}^{3} / \mathrm{s}\right)\end{array}$} & \multicolumn{4}{|c|}{ Average uncertainty in discharge measurements ( \pm percent) } \\
\hline & $\begin{array}{c}\text { Snake River below } \\
\text { Lower Salmon Falls Dam, } \\
\text { near Hagerman, Idaho } \\
(13135000)\end{array}$ & $\begin{array}{c}\text { Snake River below } \\
\text { Bliss Dam, near } \\
\text { Bliss, Idaho } \\
\text { (13153776) }\end{array}$ & $\begin{array}{c}\text { Snake River below } \\
\text { C J Strike Dam, near } \\
\text { Grandview, Idaho } \\
\text { (13171620) }\end{array}$ & $\begin{array}{c}\text { Snake River below } \\
\text { Swan Falls Dam, near } \\
\text { Murphy, Idaho } \\
(13172500)\end{array}$ \\
\hline 3,900 & NA & NA & NA & NA \\
\hline 5,600 & 4.5 & NA & 7.8 & 5.0 \\
\hline 6,000 & 4.5 & ${ }^{1} 6.0$ & 7.8 & 4.8 \\
\hline 7,000 & 4.3 & 6.3 & 7.8 & 4.4 \\
\hline All measured streamflows & 4.3 & 6.1 & 5.0 & 4.0 \\
\hline \multirow[b]{2}{*}{$\begin{array}{l}\text { Adjusted Average } \\
\text { Daily Flow threshold or } \\
\text { warning level } \\
\left(\mathrm{ft}^{3} / \mathrm{s}\right)\end{array}$} & \multicolumn{4}{|c|}{ Uncertainty in computed discharge based on 95 -percent prediction intervals ( \pm percent) } \\
\hline & $\begin{array}{c}\text { Snake River below } \\
\text { Lower Salmon Falls Dam, } \\
\text { near Hagerman, Idaho } \\
(13135000)\end{array}$ & $\begin{array}{l}\text { Snake River below } \\
\text { Bliss Dam, near } \\
\text { Bliss, Idaho } \\
(13153776)^{2}\end{array}$ & $\begin{array}{c}\text { Snake River below } \\
\text { C J Strike Dam, near } \\
\text { Grandview, Idaho } \\
\text { (13171620) }\end{array}$ & $\begin{array}{l}\text { Snake River below } \\
\text { Swan Falls Dam, near } \\
\text { Murphy, Idaho } \\
(13172500)\end{array}$ \\
\hline 3,900 & 9.3 & NA & NA & 10.1 \\
\hline 5,600 & 8.7 & NA & ${ }^{3} 13.6$ & 6.0 \\
\hline 6,000 & 8.6 & NA & 10.9 & 5.3 \\
\hline 7,000 & 8.4 & NA & 9.5 & 4.5 \\
\hline
\end{tabular}

\footnotetext{
${ }^{1}$ Based on only one measurement.

${ }^{2}$ Uncertainty in computed discharge could not be determined using prediction intervals for the Snake River below Bliss Dam (13153776) because of the high degree of curvature in the rating at low discharge.

${ }^{3}$ Calculated based on prediction intervals for instantaneous computed discharge.
}

\section{Snake River below Swan Falls Dam, near Murphy, Idaho (Site 13172500)}

Estimated uncertainty in individual discharge measurements made at the Murphy streamgage during WYs 2007-11 ranged from 2.0 to 10 percent (not shown in table 6). Average uncertainty was 4.0 percent for all measurements and 5.0 percent for measurements of less than $5,600 \mathrm{ft}^{3} / \mathrm{s}$ (table 6). In WYs 2007-11, the lowest discharge measured was 4,530 $\mathrm{ft}^{3} / \mathrm{s}$, and the lowest computed average daily discharge was $4,430 \mathrm{ft}^{3} / \mathrm{s}$ (in July 2008). As a result, uncertainty in discharge measurements could not be assessed at the $3,900 \mathrm{ft}^{3} / \mathrm{s}$ threshold, but the prediction interval could be calculated because the rating extends to less than the lowest measured discharge. Similar to other evaluated streamgages, discharges near the $3,900 \mathrm{ft}^{3} / \mathrm{s}$ threshold are rare, so uncertainty in computed discharge might be even higher than what is represented by the prediction interval at this threshold because of a lack of measurements available to define the stage-discharge rating.

Stage-discharge rating 8.2 was in effect from October 1996 to April 2011, when rating 9.1 was activated and used throughout WY 2013. Rating 9.1 was developed after high discharges because of a change in the control, presumably in WY 2011. Ratings 8.2 and 9.1 were similar at discharges less than $10,000 \mathrm{ft}^{3} / \mathrm{s}$. Prediction intervals were calculated using the part of rating 9.1 at discharges less than $10,000 \mathrm{ft}^{3} / \mathrm{s}$. Discharge uncertainty ranged from 4.5 percent at the $7,000 \mathrm{ft}^{3} / \mathrm{s}$ threshold to 10.1 percent at the $3,900 \mathrm{ft}^{3} / \mathrm{s}$ threshold (table 6). Nearly all the uncertainty represented by the prediction interval consists of measurement uncertainty for discharges from 5,600 to 7,000 $\mathrm{ft}^{3} / \mathrm{s}(4.4-5.0$ out of 4.5-6.0 percent). The remaining uncertainty between the discharge measurement uncertainty and prediction interval probably results from uncertainty in stage measurements. The need to apply periodic corrections to stage data at this streamgage, which are required because of stage sensor drift and movement, probably contributes as much as 1 percent of the total discharge uncertainty. Overall uncertainty in discharge at this streamgage increases as discharge decreases, primarily because of the limited number of measurements made at less than $5,600 \mathrm{ft}^{3} / \mathrm{s}$. Prediction intervals for computed average daily discharge in WY 2011 (fig. 9) show the range of expected true discharges for that period, although discharges at the lower prediction interval were not less than the $5,600 \mathrm{ft}^{3} / \mathrm{s}$ threshold in WY 2011. 


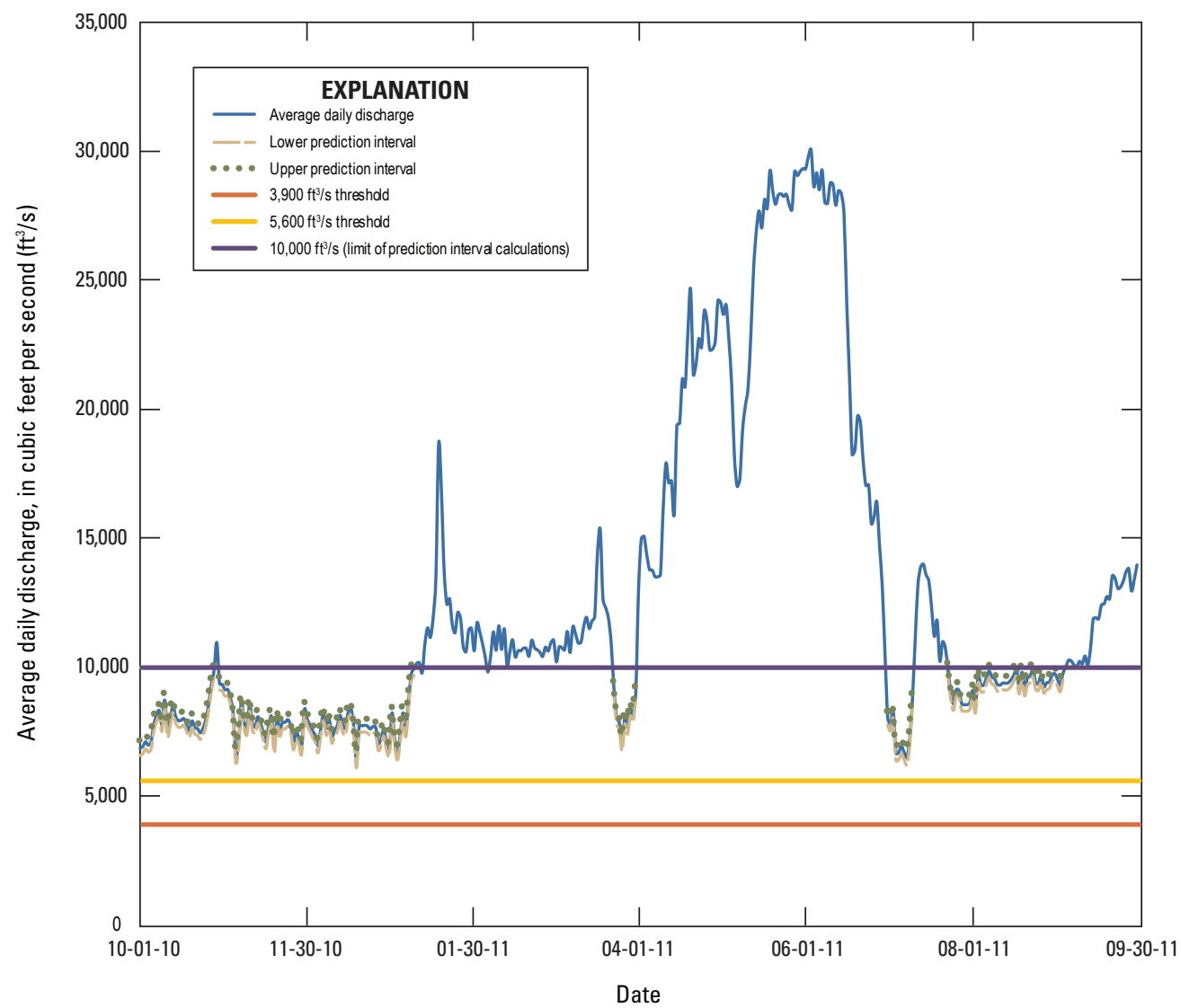

Figure 9. Computed average daily discharge and 95-percent prediction intervals for discharges less than 10,000 cubic feet per second at streamgage Snake River below Swan Falls Dam, near Murphy, Idaho (13172500), water year 2011.

As stated in the section, "Description of Streamgages," the control for the Murphy streamgage is affected by aquatic vegetation growth, which requires frequent large shifts to the stage-discharge rating. The magnitude of required shifts has increased over time. If low discharge measurements (less than $10,000 \mathrm{ft}^{3} / \mathrm{s}$ ) made in WY 2011 were not shifted, computed discharges would be biased 14 percent high, on average. Uncertainty in computed discharge between measurements owing to changes in aquatic vegetation growth at the control was not assessed in this study and probably is higher than what can be represented by the prediction intervals. More frequent measurements (for example, weekly and occasionally diurnally, throughout the day and evening if possible) might be needed during periods of aquatic vegetation growth and death to accurately define changes in shifts to the rating.

\section{Implications for Measuring and Reporting Discharge at the Murphy Streamgage}

All streamgages and discharge measurements have some level of uncertainty that cannot be eliminated entirely. Knowledge of uncertainty at the flow thresholds identified in the partial decrees for hydropower and minimum flow water rights is useful for developing a protocol for measuring and reporting the Adjusted Average Daily Flow at the Murphy streamgage. The calculation and display of prediction intervals around the Adjusted Average Daily Flow at the Murphy streamgage would help convey uncertainty and would be a useful component of the measurement and reporting protocol developed by the SFTWG.

\section{Potential Opportunities for Reducing Uncertainty}

Uncertainty in discharge might be reduced in two elements of streamgage operation that compose the largest source of overall uncertainty: (1) discharge measurements (particularly site and number of transects), and (2) frequent shifting because of aquatic vegetation growth on the streamgage control. Measurement uncertainty might be reduced by selecting better measurement cross sections during low discharge than those used in this study, particularly at the Bliss and C J Strike streamgages. Additional field reconnaissance and bathymetric surveys would be useful to determine whether better measurement sites are available. 
Idaho Power Company discharge measurements meet the minimum USGS requirements for duration of and number of transects in a measurement. The random uncertainty component of total discharge measurement uncertainty could be reduced by collecting more transects, as demonstrated in equation 1 . The term $\left(t \frac{\alpha}{2} / \sqrt{n}\right)$ in equation 1 is reduced when the number of transects is increased. The calculated, statistical random uncertainty would be reduced to less than the $\mathrm{COV}$ if measurements consisted of at least eight transects. Collecting eight or more transects increases the total duration of the measurement, called "exposure time," which is a critical factor in reducing measurement uncertainty (Oberg and Mueller, 2007). In steady-state discharge conditions, random variability as a result of small-scale turbulence and velocity fluctuations is better represented in a measurement with a long exposure time, with limits as much as those identified in Oberg and Mueller (2007). Estimated uncertainty in discharge measurements made at the Murphy streamgage was lower during the November 2012 and July 2013 seepage studies (1.1-2.1 percent) than during the period of the uncertainty evaluation in WYs 2007-11 (average 4.0 percent), partially because the seepage study measurements had more transects and longer exposure times.

More measurements made during periods of low discharge, when they occur, might improve rating definition, reduce uncertainty as determined using prediction intervals, and more accurately define shifts resulting from aquatic vegetation growth and death. Shifts in stage-discharge ratings resulting from aquatic vegetation can be quantified accurately only when a measurement is made and are typically interpolated over time between measurements. These shifts are particularly large for the Murphy streamgage compared to other evaluated streamgages in the study reach. More frequent measurements-weekly and, on occasion, diurnal if possible-would be beneficial during periods of aquatic vegetation growth and death and low discharges to more accurately define shifts. Additionally, Idaho Power Company could consider installing either (1) a stage-discharge streamgage closer to the Swan Falls Dam in an area less affected by aquatic vegetation, or (2) an index-velocity streamgage at an appropriate alternative cross section, to determine whether a new streamgage would provide more accurate and reliable discharge records. An index-velocity streamgage typically is less susceptible to changes at a control (such as heavy aquatic vegetation, scour, and infilling by sediment) and responds more rapidly to discharge changes at the dam than a stage-discharge streamgage. Discharge computed at an index-velocity streamgage could have higher uncertainty, however, because two ratings (stage-area and index velocity-average velocity ratings) are required, whereas a stage-discharge streamgage requires only one rating. Additionally, the velocity data collected at an index-velocity streamgage can be highly variable at low discharges because of limitations in the instruments used and because wind can overcome river momentum and substantially affect water velocities. If an index-velocity streamgage is selected, the site should have a consistent, measurable zone of higherthan-average velocities relative to the overall average channel velocity and should be relatively free of aquatic vegetation (Levesque and Oberg, 2012).

\section{Summary and Conclusions}

The State of Idaho, Idaho Power Company, and other interested parties seek to develop a mutually acceptable protocol for measuring and reporting average daily flow, adjusted to remove fluctuations resulting from the operation of Idaho Power Company facilities (referred to as "Adjusted Average Daily Flow"), and to quantify associated uncertainty at the Snake River below Swan Falls Dam, near Murphy, Idaho, streamgage. The information will be used to facilitate distribution of water to owners of hydropower and minimum flow water rights as identified through partial decrees in the Snake River Basin Adjudication process. Two methods are being evaluated to calculate Adjusted Average Daily Flow, which accounts for (or removes) the effects of Idaho Power Company hydropower operations: (1) the Reservoir-Stage Method and (2) the Flow Method. To assist in this endeavor, the U.S. Geological Survey (USGS) completed a seepage analysis for the middle Snake River from King Hill to near Murphy, Idaho, and evaluated uncertainty in discharge measurements and computed discharge at four streamgages operated by Idaho Power Company.

Crews consisting of USGS, Idaho Department of Water Resources, and Idaho Power Company employees made a series of discharge measurements and calculated seepage in the middle Snake River during November 2012, irrigation season, and during July 2013, non-irrigation season. Discharge was measured at main-stem sites and inflows from tributaries and springs in both seepage studies. The hydrologic system during the July 2013 seepage study was more complex than during the November 2012 study because numerous outflows from irrigation diversions and inflows from irrigation returns, inactive during November 2012 study, were measured and incorporated in the seepage calculations for the July 2013 study.

Seepage greater than discharge measurement uncertainty was measured in four reach segments during the November 2012 seepage study, but in none of the reach segments in the July 2013 seepage study. Seepage measured in the subreach between C J Strike Dam and Murphy was less than the measurement uncertainty for both seepage studies in November 2012 and July 2013, so nothing definitive can be derived about seepage in this subreach. The overall subreach between King Hill and C J Strike Dam had a meaningful net seepage gain of 415 cubic feet per second $\left(\mathrm{ft}^{3} / \mathrm{s}\right)$ in the November 2012 seepage study, which is similar to seepage 
estimated in $1991\left(461 \mathrm{ft}^{3} / \mathrm{s}\right)$ using a groundwater-flow model. The meaningful seepage estimated during the November 2012 study was about 5.8 percent of the measured discharge at the Murphy streamgage. Cumulative measurement uncertainty was higher during the July 2013 seepage study than during the November 2012 seepage study because more measurements were included in the calculation for each reach in July. Although seepage conditions in the study area can vary throughout seasons and among years because of changes in hydrology and climate, the calculated, meaningful seepage estimates are considered representative of typical seepage conditions expected during the non-irrigation season near the minimum Adjusted Average Daily Flow thresholds (3,900 ft $\mathrm{ft}^{3} / \mathrm{s}$ from April 1 to October 31, and 5,600 ft $3 / \mathrm{s}$ from November 1 to March 31). If the Flow Method is selected for calculating Adjusted Average Daily Flow at the Murphy streamgage, the meaningful seepage estimate of $217 \mathrm{ft}^{3} / \mathrm{s}$ in the subreach between Loveridge Bridge and C J Strike Dam may need to be included in the routing and adjustment of flow at the Murphy streamgage during non-irrigation season. Seepage estimates determined for the irrigation season were less than cumulative measurement uncertainty and are not meaningful for use in the calculation of Adjusted Average Daily Flow at the Murphy streamgage, unless future changes in hydrologic conditions in the study area result in changes in the interaction between groundwater and surface water.

The USGS also evaluated the uncertainty of stage and velocity (where applicable) data, discharge measurements, and computed discharge at selected streamgages operated by Idaho Power Company in the Snake River between Milner Dam and downstream of Swan Falls Dam near Murphy, Idaho. Average daily discharge at the Murphy streamgage was greater than the 3,900 and 5,600 $\mathrm{ft}^{3} / \mathrm{s}$ Adjusted Average Daily Flow thresholds during the period of evaluation in WYs 2007-11. Equipment and techniques used to collect discharge data at evaluated streamgages met the guidelines and minimum accuracy requirements established by the USGS. Prediction intervals were calculated where possible to quantify uncertainty in average daily discharge at the two Adjusted Average Daily Flow thresholds (3,900 and 5,600 $\mathrm{ft}^{3} / \mathrm{s}$ ) as well as at two additional discharges selected arbitrarily by USGS as "warning" levels for low discharge $(6,000$ and $7,000 \mathrm{ft}^{3} / \mathrm{s}$ ). In some cases, prediction intervals could not be calculated for the low thresholds because of non-linearities in the discharge rating or a lack of discharge measurements. Average uncertainty in discharge measurements for the four streamgages ranged from 4.3 percent (Lower Salmon Falls) to 7.8 percent (C J Strike Dam) for discharges less than $7,000 \mathrm{ft}^{3} / \mathrm{s}$ in WYs 2007-11. These uncertainties constituted most of the total quantifiable uncertainty in discharge records, represented by the prediction intervals calculated for each streamgage discharge rating. Total quantifiable uncertainty in computed discharge at the Murphy streamgage was 10.1 and
6.0 percent at the Adjusted Average Daily Flow thresholds of 3,900 and $5,600 \mathrm{ft}^{3} / \mathrm{s}$, respectively.

All streamgages and discharge measurements have some level of uncertainty that cannot be eliminated entirely. Uncertainty might be reduced in two elements of streamgage operation that compose the largest source of overall uncertainty for the study reach: discharge measurements (particularly site selection and number of transects) and frequent shifting resulting from aquatic vegetation on the streamgage control. Discharge measurement uncertainty might be reduced by selecting better measurement cross sections during low discharge than those used during this study, if they exist, particularly for the C J Strike and Bliss streamgages. The random uncertainty component of total discharge measurement uncertainty might be reduced by collecting eight or more transects and increasing overall duration of the measurement, particularly at discharges near the thresholds identified in the partial decrees. Additionally, more measurements are desirable during periods of low discharge, when they occur, to improve rating definition and to more accurately define shifts resulting from aquatic vegetation. Seasonal aquatic vegetation growth on the control for the Murphy streamgage requires frequent large shifts to measured stages to calculate more accurate discharges. These shifts can be quantified accurately only when a measurement is made and are assumed by Idaho Power Company to linearly vary with time between measurements. More frequent measurements - weekly and perhaps diurnalare desirable during periods of aquatic vegetation growth and death and low discharges to more accurately define shifts. A possible alternate site for a streamgage could be investigated to determine if more accurate and reliable discharge records could be developed for measuring and reporting the Adjusted Average Daily Flow for purposes of distributing water to owners of hydropower and minimum flow water rights in accordance with their partial decrees and Idaho law.

\section{Acknowledgments}

The U.S. Geological Survey (USGS) wishes to thank the members of the Swan Falls Technical Working Group for technical guidance and support throughout the project: Sean Vincent, Elizabeth Cresto, and David Hoekema of the Idaho Department of Water Resources (IDWR); Peter Vidmar and Jon Bowling of Idaho Power Company; Christian Petrich of SPF Water Engineering; Charles Brendecke of AMEC Environment and Infrastructure; and Greg Sullivan of Spronk Water Engineers. Special thanks also go to Corbin Knowles, Dennis Owsley, and Craig Tesch of the IDWR, who provided miscellaneous data for the seepage analysis. Finally, the authors acknowledge the efforts of the USGS, IDWR, and Idaho Power Company personnel who collected discharge data for the study. 


\section{References Cited}

Bendixsen, S., 1994, Summary of hydrologic conditions in the Mountain Home and Cinder Cone Butte areas: Idaho Department of Water Resources Open-File Report, 19 p., accessed December 11, 2013, at http:/www.idwr.idaho. gov/WaterInformation/Publications/ofr/ofr-gw_conditions mhgwma.pdf.

Hortness, J.E., and Vidmar, Peter, 2005, Surface-water/ ground-water interaction along reaches of the Snake River and Henrys Fork, Idaho: U.S. Geological Survey Scientific Investigations Report 2004-5115, 18 p., 3 apps., http://pubs. usgs.gov/sir/2004/5115/.

Kennedy, E.J., 1983, Computation of continuous records of streamflow: U.S. Geological Survey Techniques of WaterResources Investigations, book 3, chap. A13, 52 p., http:// pubs.usgs.gov/twri/twri3-a13/.

Kjelstrom, L.C., 1986, Flow characteristics of the Snake River and water budget for the Snake River Plain, Idaho and eastern Oregon: U.S. Geological Survey Hydrologic Atlas 680, 2 maps., scale: 1:1,000,000, http://pubs.er.usgs.gov/ publication/ha680.

Lapin, L., 1997, Modern engineering statistics: Belmont, Calif., Wadsworth Publishing Company, 583 p.

Levesque, V.A., and Oberg, K.A., 2012, Computing discharge using the index velocity method: U.S. Geological Survey Techniques and Methods, book 3, chap. A23, 148 p., http:// pubs.usgs.gov/tm/3a23.

Lindholm, G.F., Garabedian, S.P., Newton, G.D., and Whitehead, R.L., 1988, Configuration of the water table and depth to water, spring 1980, water-level fluctuations, and water movement in the Snake River Plain Regional Aquifer System, Idaho and eastern Oregon: U.S. Geological Survey Hydrologic Atlas 703, 1 pl., scale 1:500,000, http://pubs. er.usgs.gov/publication/ha703.

Mueller, D.S., and Wagner, C.R., 2009, Measuring discharge with acoustic Doppler current profilers from a moving boat: U.S. Geological Survey Techniques and Methods, book 3, chap. A22, 72 p., http://pubs.usgs.gov/tm/3a22.

Newton, G.D., 1991, Geohydrology of the regional aquifer system, western Snake River Plain, southwestern Idaho: U.S. Geological Survey Professional Paper 1408-G, 59 p., http://pubs.er.usgs.gov/publication/pp1408G.

Norton, M.A., Ondrechen, W., and Baggs, J.L., 1982, Ground water investigation of the Mountain Home plateau: Idaho Department of Water Resources Open-File Report, 67 p., http://www.idwr.idaho.gov/WaterInformation/Publications/.
Oberg, K.A., and Mueller, D.S., 2007, Validation of streamflow measurements made with acoustic Doppler current profilers: Journal of Hydraulic Engineering, v.133, no. 12, p. 1421-1432., accessed August 17, 2013, at http:// hydroacoustics.usgs.gov/publications/14-Oberg-Mueller. pdf.

Ralston, D.R., and Chapman, S.L., 1968, Ground-water resource of the Mountain Home area, Elmore County, Idaho: Idaho Department of Reclamation Water Information Bulletin No. 4, 71 p., accessed December 11, 2013, at http:// www.idwr.idaho.gov/WaterInformation/Publications/.

Rantz, S.E., 1982, Measurement and computation of streamflow_Volume 2, computation of discharge: U.S. Geological Survey Water Supply Paper 2175, 631 p., http:// pubs.usgs.gov/wsp/wsp2175/.

Sauer, V.B., and Turnipseed, D.P., 2010, Stage measurement at gaging stations: U.S. Geological Survey Techniques and Methods, book 3, chap. A7, 45 p., http://pubs.usgs.gov/tm/ tm3-a7/.

Simonds, F.W., and Sinclair, K.A., 2002, Surface waterground water interactions along the Lower Dungeness River and vertical hydraulic conductivity of streambed sediments, Clallam County, Washington, September 1999-July 2001: U.S. Geological Survey Water-Resources Investigations Report 02-4161, 69 p., http://pubs.usgs.gov/ wri/wri024161/.

SonTek/Yellow Springs Instruments, 2009, FlowTracker ${ }^{\circledR}$ handheld ADV technical manual, firmware version 3.7, software version 2.30: SonTek/YSI, San Diego, Calif., $116 \mathrm{p}$.

State of Idaho, 2005, Appropriation of water-Permits, certificates, and licenses-Survey, chap. 2 of Irrigation and Drainage - Water rights and reclamation: Idaho Statutes 42-203B(2), accessed January 4, 2014, at http://www. legislature.idaho.gov/idstat/Title42/T42CH2SECT42-203B. htm.

State of Idaho, 2011a, Snake River Basin adjudication case no. 39576-Partial decrees pursuant to I.R.C.P. 54 (b) for water right nos. 02-100, 02-2032A, 02-4000A, 02-4001A, 02-4000B, 02-4001B, 02-2032B, 02-2036, 02-2056, 02-2065, 02-2064, 02-10135, 02-2060, 02-2059, 02-2001B, 02-2001A, 02-2057, 37-2128, 37-2472, 37-2471, 37-20710, 37-20709, 36-2013, 36-2018, 36-2026, 02-201, 02-223, and 02-224: District Court of the Fifth Judicial District of the State of Idaho, In and For the County of Twin Falls., accessed January 4, 2014, at http://www.srba.state.id.us/ SREPT.HTM. 
State of Idaho, 2011b, Snake River Basin adjudication case no. 39576, subcase no. 00-91013-Order withdrawing issue no. 4: District Court of the Fifth Judicial District of the State of Idaho, In and For the County of Twin Falls, accessed January 4, 2014, at http://www.srba.state.id.us/ SREPT.HTM.

State of Idaho, 2011c, Snake River Basin adjudication case no. 39576, subcase no. 00-92002GP-Order of partial decree for general provisions in basin 02: District Court of the Fifth Judicial District of the State of Idaho, In and For the County of Twin Falls, accessed March 27, 2014, at http://www.srba. state.id.us/SREPT.HTM.

State of Idaho, 2012, Idaho state water plan: Idaho Water Resource Board, 90 p., accessed January 4, 2014, at http://www.idwr.idaho.gov/waterboard/WaterPlanning/ StateWaterPlanning/PDFs/ADOPTED \%20State $\% 20$ Water\%20Plan\%202012.pdf.

State of Idaho, 2014, Idaho water adjudications: State of Idaho Web site, accessed March 17, 2014, at http://www.srba. state.id.us/.

Turnipseed, D.P., and Sauer, V.B., 2010, Discharge measurements at gaging stations: U.S. Geological Survey Techniques and Methods, book 3, chap. A8, 87 p., http:// pubs.usgs.gov/tm/tm3-a8/.
U.S. Geological Survey, 2011, Exposure time for ADCP moving-boat discharge measurements made during steady flow conditions: U.S. Geological Survey Office of Surface Water Technical Memorandum SW 11.08, September 19, 2011, accessed August 17, 2013, at http://water.usgs.gov/ osw/pubs/memo.summaries.html.

U.S. Geological Survey, 2014, National Water Information System (NWISWeb): U.S. Geological Survey database, accessed May 21, 2014, at http://waterdata.usgs.gov/nwis/.

Western Regional Climate Center, 2014, Monthly average pan evaporation data by state: Western Regional Climate Center database, accessed March 11, 2014, at http://www.wrcc.dri. edu/htmlfiles/westevap.final.html.

Williams, M.L., 2011, Seasonal seepage investigation on an urbanized reach of the lower Boise River, southwestern Idaho, water year 2010: U.S. Geological Survey Scientific Investigations Report 2011-5181, 24 p., http://pubs.usgs. gov/sir/2011/5181/.

Williams, M.L., 2014, Groundwater level and nitrate concentration trends on Mountain Home Air Force Base, southwestern Idaho: U.S. Geological Survey Open-File Report 2014-1022, 49 p., http://dx.doi.org/10.3133/ ofr20141022. 
Publishing support provided by the U.S. Geological Survey Publishing Network, Tacoma Publishing Service Center

For more information concerning the research in this report, contact the Director, Idaho Water Science Center

U.S. Geological Survey

230 Collins Road

Boise, Idaho 83702

http://id.water.usgs.gov 
